\title{
O AKTUALNOSTI CASUUM COMMORIENTIUM U RIMSKOM I SUVREMENOM EUROPSKOM PRIVATNOM PRAVU
}

Sažetak: $\quad$ Urimskojpravnojtradiciji, ali i suvremenimgrađanskopravnim sustavima pojmom commorientes (komorijenti, suumirući) označavaju se osobe umrle u istoj nesreći ili drugoj opasnosti, nalazeći se međusobno u pravnom položaju relevantnom za nasljedno pravo. U vezi s rješavanjem ovakvih situacija u privatnopravnoj teoriji dolazi do razvoja različitih pravnih presumpcija još od razdoblja klasičnog rimskog prava. Sve te presumpcije moguće je sistematizirati u okviru dvaju osnovnih koncepata - prvog, utemeljenog na presumiranju nadživjelosti subjekata i drugog, utemeljenog na presumiranju istovremenosti smrti subjekata.

Poredbeno promatrajući u razvoju europskog privatnog prava došlo je do recepcije obaju koncepata, s tim da će s vremenom koncept istovremenosti, gotovo u potpunosti, potisnuti koncept nadživjelosti. U radu se analiziraju razlozi zbog kojih do toga dolazi. Uspostavljajući vezu između rimskih korijena i europskog privatnog prava posebna pozornost posvećuje se mogućnosti primjene presumpcija u odnosu na slučajeve kada između smrti osoba postoji određena prostorna ili vremenska udaljenost ili ako je različit uzrok doveo do smrtnih posljedica. $U$ konačnici rad jasno ukazuje na važnost rimskih pravila koja katkad mogu imati fundamentalni značaj u razumijevanju instituta suvremenog privatnog prava.

Ključne riječi: $\quad$ commorientes, rimsko pravo, nasljedno pravo, europsko privatno pravo, Code civil, Njemački građanski zakonik, Austrijski građanski zakonik 


\section{UVODNE NAZNAKE**}

Simultane smrti osoba koje se nalaze u međusobnom položaju relevantnom za nasljedno pravo nisu rijetka pojava. Ako je redoslijed njihovih smrti nepoznat ili ne može biti utvrđen, to može imati ozbiljne posljedice u procesu prijenosa prava i obveza.

U rimskoj pravnoj tradiciji, ali i suvremenim građanskopravnim sustavima pojmom commorientes (komorijenti, suumirući) označavaju se osobe umrle u istoj nesreći ili drugoj opasnosti, nalazeći se međusobno u pravnom položaju relevantnom za nasljedno pravo. Etimološki gledano, izraz potječe od latinske riječi commorior što bi u doslovnom prijevodu značilo umrijeti zajedno. ${ }^{1}$ U okviru Corpus iuris civilisa, izraz se pojavljuje u okviru Digesta, u Ulpijanovu tekstu iz D. 24. 1. 32. 14., u obliku licet de commorientibus oratio non senserit. U Digestama susrećemo i izraze simul perierint (Usp. Tryph. D. 34. 5. 9. 3. ili Papin. D. 28. 6. 42.), simul obissent (Usp. Marci. D. 36. 1. 35.), simul functus (Usp. Marci. D. 34. 5. 18. 1.), pariter decesserint (Usp. Marci. D. 34. 5. 18. pr. ili Marci. D. 39. 6. 26.) i pariter mortuis (Usp. Marci. D. 34. 5. 16. pr.). Promatrajući kontekstualno, navedeni izrazi predstavljaju istoznačnice budući da se koriste $s$ ciljem označavanja iste situacije, odnosno smrti više osoba uz prisutnost elementa neizvjesnosti o tome tko je koga nadživio.

Imajući u vidu složenost rješavanja pitanja istovremene smrti, u privatnopravnoj teoriji došlo je do razvoja različitih pravnih presumpcija još od razdoblja klasičnog rimskog prava. Sve te presumpcije moguće je sistematizirati u okviru dvaju osnovnih koncepata - prvog, utemeljenog na presumiranju nadživjelosti subjekata i drugog, utemeljenog na presumiranju istovremenosti smrti subjekata. Poredbeno promatrajući u razvoju europskog privatnog prava došlo je do recepcije obaju koncepata, s tim da će s vremenom koncept istovremenosti, gotovo u potpunosti, potisnuti koncept nadživjelosti. U radu se analiziraju razlozi zbog kojih do toga dolazi. Uspostavljajući vezu između rimskih korijena i europskog privatnog prava, posebna pozornost posvećuje se analizi mogućnosti primjene presumpcija u odnosu na slučajeve kada između smrti osoba postoji određena prostorna ili vremenska udaljenost ili ako je različit uzrok doveo do smrtnih posljedica.

U udžbenicima rimskog, ali i suvremenog građanskog prava, ne pridaje se veća pozornost ovim pitanjima, koja osim što su važna za privatnopravnu teoriju, mogu imati i značajne reperkusije u praktičnoj primjeni prava. ${ }^{2}$

** Rad je nastao u okviru znanstvenog projekta "Presumpcija smrti u bosanskohercegovačkom i europskom pravu" realiziranog u okviru podrške Međunarodnog komiteta Crvenog križa BiH, a u okviru projekta podrške znanstvenim istraživanjima problema nestalih osoba te individualnih i društvenih posljedica neizvjesnog gubitka. Sadržaj, zaključci i stavovi isključiva su odgovornost autora te ne predstavljaju stavove MKCK-a.

1 U drugim jezicima: engl. commorientes; njem. Kommorienten; franc. comourantas; tal. commorienza. Usp. Vladimir Pezo (ed), Pravni leksikon (Leksikografski zavod Miroslav Krleža 2007) 599.

2 U većini udžbenika rimskog prava na našem jezičnom području pitanje komorijenata uopće se ne spominje. Usp. Marijan Horvat, Rimsko pravo (Pravni fakultet u Zagrebu 2017); Antun Malenica i Nataša Deretić, Rimsko pravo (Pravni fakultet u Novom Sadu 2011); Dragomir Stojčević, Rimsko privatno pravo (Savremena administracija 1978); Janez Kranjc, Rimsko pravo (Ius Software \& GV Založba 2017). Ovo pitanje ne obrađuje ni udžbenik građanskog prava Vedriš - Klarić koji ima vrlo široku uporabu na našem području. Usp. Petar Klarić i Martin Vedriš, Građansko pravo (Narodne novine 2006). U udžbeniku nasljednog prava Gavella Belaj o komorijentima se piše vrlo kratko u okviru jedne podnožne bilješke. Usp. Nikola Gavella i Vlado Belaj, Nasljedno pravo (Narodne novine 2008) 91. Slična situacija je i sa stranim udžbenicima/priručnicima, gdje se ova pitanja uopće ne obrađujuju ili su obrađena vrlo fragmentirano. Usp. George Mousourakis, Fundamentals of Roman Private Law (Springer 2012); Biondo Biondi, Il diritto Romano (Editore Licino Cappelli 1957); Pietro Bonfante, Istituzioni di diritto Romano (Casa Editrice Dott. F. Vallardi 1925); Paul J. du Plessis, Clifford Ando and Kaius Tuori (eds), The Oxford Handbook of Roman Law and Society (OUP 2016); Max 


\section{CASUS COMMORIENTIUM U RIMSKOM PRAVU}

Promatrajući romanistiku na našem području, problem zajedničke smrti više osoba u položaju relevantnom za nasljedno pravo bio je predmet interesa V. Radovčić još 1964. godine. ${ }^{3}$ U kratkoj analizi autorica je minuciozno dovela u pitanje dotad postavljene teze o vremenu postanka presumpcija u rimskom pravu. O ispravnosti njezinih stavova u nastavku osvrnut ćemo se kroz prizmu moderne romanistike. Kad je riječ o nešto širem pristupu institutu komorijenata, smatramo kako je tu najveći doprinos dao D. Radoman. ${ }^{4}$ Iako je njegov rad primarno usmjeren na recepciju instituta komorijenata u tadašnje zakonodavstvo i Srpski građanski zakonik, jednim dijelom dotiče i razvoj instituta u rimskim pravnim izvorima. ${ }^{5}$

S aspekta razumijevanja pravne prirode instituta Radomanov doprinos ogleda se kroz elaboraciju casus commorientis kao oblika pravne presumpcije, a ne fikcije kako to pojedini autori navode. ${ }^{6}$ Podržavajući Radomanov stav, smatramo važnim istaknuti kako pogrešno razumijevanje ovog instituta za posljedicu može imati nemogućnost izvođenja protudokaza, a u konačnici i pogrešnog utvrđivanja činjeničnog stanja.

$\mathrm{Na}$ tragu navedenog, s teorijskog aspekta za razumijevanje prirode instituta važno je razgraničiti nekoliko pojmova. U domaćoj pravnoj doktrini većina autora pretpostavke razlikuje od fikcija ovisno o tome postoji li nesigurnost u vezi s određenim postojanjem. Uzme li se neko postojanje svjesno kao istinito, a u stvarnosti je neistinito i ne postoji, govorimo o fikcijama. ${ }^{7}$ U odnosu na takve činjenice jasno je kako ne postoji mogućnost dokazivanja suprotnog. S druge strane, kod presumpcija pravo se zadovoljava naslućivanjem ili vjerojatnošću. Kod takvih činjenica uvijek postoji mogućnost izvođenja protudokaza kojim bi se činjenica mogla oboriti. S obzirom na mogućnost izvođenja protudokaza u teoriji su se razvile i neoborive presumpcije (tzv. presumptiones iuris et de iure), koje su prema svojoj prirodi bliže pojmu fikcije, premda ni takve presumpcije nisu fikcije jer je kod fikcija uvijek potpuno jasno kako je riječ o činjenicama koje su neistinite u stvarnosti, ali i dalje ih držimo za istinite. ${ }^{8}$

Kad je riječ o komorijentima, treba uzeti u obzir da je posrijedi neizvjesna situacija u okviru koje je često riječ o dugom čekanju u svrhu utvrđivanja pravog stanja stvari ili nemogućnosti

Kaser, Das römische Privatrecht (Beck 1955) 237; Adolf Berger, Encyclopedic Dictionary of Roman Law (American Philosophical Society 1953) 400; Edoardo Volterra, Istituzioni di diritto privato romano (Edizioni Ricerche 1961) 48.

3 Vesna Radovčić, 'Nešto o rimskim presumpcijama kod zajedničke smrti više osoba u istoj nesreći' (1964) 14(3-4) Zbornik Pravnog fakulteta u Zagrebu 159-64.

4 Op. a. Dr. sc. Dušan P. Radoman (Cetinje, 1911. - Sombor, 1984.), odvjetnik i prvi profesor Rimskog prava na Pravnom fakultetu u Osijeku (1976. - 1982.).

5 Dušan Radoman, 'Casus commorientium u rimskom i suvremenim pravima' (1977) 27(4) Zbornik Pravnog fakulteta u Zagrebu 325-34. Radoman se ovim fenomenom u kontekstu suvremenog prava bavio i u članku: Dušan Radoman, 'Dve pretpostavke o komorijentima' (1958) 7(9) Glasnik advokatske komore Vojvodine 2-6.

6 Razumijevanje suprotno našem vidljivo je i u: Obrad Stanojević, Rimsko pravo (Magistrat 2000) 145; Ivo Puhan, Rimsko pravo (Naučna knjiga 1969) 137. Također i u okviru pandektistike. Usp. Aleksandar Egersdorfer, Predavanja dr. Aleksandra Egersdorfera o pandektama, vol 1 (Naklada Jugoslovenske štampe 1928) 52. Ovakva pogreška u razmijevanju bit će ispravljena u svesku predavanja o pandektama B. Eisnera. Usp. Bertold Eisner, Pandekta (Klub slušača prava 1938) 28-29.

7 Jedan od najpoznatnijih primjera pravne fikcije jest fikcija o nerođenom djetetu prema kojoj će se ono smatrati rođenim (iako je potpuno jasno da ono nije rođeno) u situacijama kada je riječ o njegovim probitcima (Usp. D. 1. 5. 7. Paulus libro singulari de portionibus, quae liberis damnatorum conceduntur). 
da se stanje stvari utvrdi. Ovdje je konstantno prisutna mogućnost suprotnog dokazivanja i obaranja postavljenog zaključka u svrhu utvrđivanja materijalne istine. Sam vremenski interval događaja zbog kojeg je došlo do smrti više osoba može biti duljeg ili kraćeg trajanja. Čini se logičnim, da u takvom događaju i opasnost može biti različita za različite osobe, ovisno o većem broju determinanti, među ostalim i njihovim prirodnim osobinama (zdravlje, starost i drugo). Upravo zbog ovakvog razumijevanja opravdano je i postavljeno pitanje smrti koja može nastupiti u različitim vremenskim intervalima i samim tim utjecati na međusobni prijenos prava i obveza. S pristupom određenih autora ne bismo se složili. Tako Stanojević navodi kako je rimsko pravo postavilo fikciju prema kojoj se polazilo od toga da starije lice prije umire nego mlađe, ali da odrasla osoba duže živi nego malo dijete..$^{9}$ Ovakav zaključak, iako Stanojević ne navodi izvor, mogao bi biti izveden iz D. 34. 5. 9. 2. gdje stoji kako će odrasli sin koji je poginuo zajedno s ocem, nadživjeti oca, dok će otac nadživjeti maloljetnog sina, ali autor ovdje zanemaruje nastavak u kojem stoji - si non probatur supervixisse patri filius (ako se ne dokaže kako je sin nadživio oca), ${ }^{10}$ a što nama jasno potvrđuje argument da je riječ o pravnoj presumpciji, a ne fikciji. Slično je vidljivo i u Trifoninovu fragmentu iz D. 34. 5. 9. 4. o kojem ćemo tek pisati. Na tragu izloženog, jednako kao i Radoman, smatramo kako casum commorientem treba razumijevati isključivo kao pravnu presumpciju.

U nastavku rada pokušat ćemo rekonstruirati još neke odrednice vezane uz razumijevanje casus commorientis. Uz razumijevanje instituta nameće nam se i koncept rješavanja konkretnih situacija. S tim u vezi, u rimskoj pravnoj tradiciji dolazi do razvoja različitih pravnih presumpcija još od vremena klasičnog rimskog prava. Sve te presumpcije moguće je sistematizirati u okviru dvaju osnovnih koncepata - prvog utemeljenog na presumiranju nadživjelosti subjekata i drugog utemeljenog na presumiranju istovremenosti smrti subjekata. ${ }^{11}$ Prema prvom konceptu utvrđena su određena pravila u okviru kojih se uzima da su pojedini subjekti nadživjeli druge na temelju određenih pretpostavki vezanih uz njihove prirodne karakteristike, dok prema drugom, koji će se u konačnici i šire rasprostraniti postoji pretpostavka istovremenosti smrti osoba u okviru nesretnog događaja.

\subsection{KONCEPT NADŽIVJELOSTI}

Koncept nadživjelosti u rimskom pravu razvit će se kroz izraženiju primjenu kazuističke metode identificiranjem različitih determinanti vezanih uz rješavanje casuum commorientium. U nastavku osvrnut ćemo se na neke od ključnih slučajeva vezanih uz razumijevanje ovog koncepta. Tako u izvorima stoji:

D. 34. 5. 9. 4. Tryphoninus libro 21 disputationum. Si Lucius Titius cum filio pubere, quem solum testamento scriptum heredem habebat, perierit, intellegitur supervixisse filius patri et ex testamento heres fuisse, et filii hereditas successoribus eius defertur, nisi contrari-

9 Stanojević (n 6) 145.

10 Usp. D. 34. 5. 9. 2. Tryphoninus libro 21 disputationum. Si cum filio suo libertus simul perierit intestati, patrono legitima defertur hereditas, si non probatur supervixisse patri filius: hoc enim reverentia patronatus suggerente dicimus. 
um approbetur. Quod si impubes cum patre filius perierit, creditur pater supervixisse, nisi et hic contrarium approbetur.

Ako Lucije Ticije, zajedno s punoljetnim sinom, kojega je jedinog u oporuci za svog nasljednika odredio, pogine, smatra se da je sin nadživio oca i da je na osnovi oporuke postao nasljednik, pa sinova ostavina prelazi na njegove nasljednike, ako se suprotno ne dokaže. A ako bi maloljetni sin skupa s ocem poginuo, smatra se da ga je otac nadživio, ako se i ovdje suprotno ne dokaže.

Upravo se ovaj tekst nalazi u direktnoj korelaciji s ranijim izlaganjem o razumijevanju casus commorientis kao pravne presumpcije. Naime, kako bi se olakšalo odlučivanje u nasljedničkim sporovima, uvedena je pretpostavka prema kojoj se u okolnosti zajedničke smrti roditelja i djece, ima smatrati kako su maloljetna djeca poginula pred roditeljima, a odrasla nakon roditelja. ${ }^{12}$ No, imajući u vidu pretpostavke specifične za danu situaciju, a osobito naznake o isključenju u slučaju dokazivanja suprotnog, odnosno - nisi et hic contrarium approbetur, čini nam se kako su rimski klasični pravnici ovdje imali za cilj posložiti situaciju u skladu s vjerojatnosti razmatranja danog događaja. Oni su danu situaciju posložili na način koji im je djelovao najpravičnije, uz ostavljenu mogućnost da onaj koji tvrdi suprotno to može i dokazati. ${ }^{13}$

Slične presumpcije, uvjetovane kriterijem starosti, vidljive su i u izvorima iz nastavka, uz nedvosmisleno razlikovanje situacije ovisno o tome je li riječ o doraslim ili nedoraslim srodnicima. U prvom izvoru interesantno je kako se primjena ovakvog koncepta uz kriterij starosti objašnjava humanim pristupom.

D. 34. 5. 22. Iavolenus libro quinto ex Cassio. Cum pubere filio mater naufragio periit: cum explorari non possit, uter prior exstinctus sit, humanius est credere filium diutius vixisse.

S odraslim sinom majka je poginula u brodolomu; budući da se ne može istražiti tko je od njih prvi izdahnuo, humanije je vjerovati da je sin duže živio.

D. 34. 5. 23. Gaius libro quinto ad legem Iuliam et Papiam. Si mulier cum filio impubere naufragio periit, priorem filium necatum esse intellegitur.

Ako žena s nedoraslim sinom pogine u brodolomu, smatrat će se da je sin ranije umro.

Trifoninin se pitanjem komorijanata bavio u još nekoliko paragrafa. U uskoj vezi sa SC Tertullianum ${ }^{14}$ i položajem majke prema imovini njezina djeteta u nasljednom pravu, naznačeno je kako se u slučaju smrti oca i sina za vrijeme trajanja rata, ima smatrati kako je otac

12 U situaciji vezanoj uz kćerin miraz za slučaj smrti kćeri i majke u istom događaju vidljivo je kako majčini nasljednici ne mogu tužiti za povrat miraza, budući da se u ovoj situaciji ima smatrati kako je majka prva umrla. Iako nije jasno naznačena dob kćeri, nedvosmisleno na temelju činjenica iz izvora možemo smatrati kako je kći dorasla imajući u vidu njezino ranije zaključenje braka. Usp. D. 34. 5. 16. pr. Marcianus libro tertio regularum. Quod de pariter mortuis tractamus, et in aliis agitatum est. Ut ecce si mater stipulata est dotem a marito mortua filia in matrimonio sibi reddi et simul cum filia perit, an ad heredem matris actio ex stipulatu competere? Et divus Pius rescripsit non esse commissam stipulationem, quia mater filiae non supervixit.

13 Usp. Max Kaser, 'Beweislast und Vermutung im römischen Formularprozess' (1954) 71(1) Zeitschrift der Savigny - Stiftung für Rechtsgeschichte. Romanistische Abteilung 239.

14 Just. Inst. 3. 3. 2. Postea autem senatus consulto Tertulliano, quod divi Hadriani temporibus factum est, plenissime de tristi successione matri, non etiam aviae deferenda cautum est: ut mater ingenua trium liberorum ius habens, libertina quattuor ad bona filiorum filiarumve admittatur intestatorum mortuorum, licet in potestate parentis est, ut scilicet, cum alieno iuri subiecta est, iussu eius adeat, cuius iuri subiecta est. 
umro prvi te će prema tome ostavinski dio sina iz očeve imovine pripasti majci. Kaser smatra kako Hadrijanov reskript, koji se spominje u izvoru koji slijedi, predstavlja početak razvoja presumpcije o komorijentima u klasičnom rimskom pravu. ${ }^{15}$

D. 34. 5. 9. 1. Tryphoninus libro 21 disputationum. Cum bello pater cum filio perisset materque filii quasi postea mortui bona vindicaret, adgnati vero patris, quasi filius ante perisset, divus Hadrianus credidit patrem prius mortuum.

Ondje gdje su sin i njegov otac izgubili život u ratu, a majka je potraživala imanje svoga sina zbog njegove posljednje smrti, rođaci njegova oca izjavili su da je sin umro prvi, Božanski Hadrijan je odlučio da je otac prvi umro.

Važno je imati na umu kako je i u ovom slučaju situacija posložena u skladu s vjerojatnosti razmatranja danog događaja. Naime, iako sinova dob nije naznačena, kontekstualno promatrajući izvor, treba uzeti u obzir kako u razdoblju principata rimske legije bivaju popunjene najvećim dijelom rimskim građanima dobrovoljcima (tzv. voluntarii) u dobi između 17 i 20 godine. ${ }^{16}$ Prema tome, iako u izvoru nije naznačeno, možemo smatrati kako je descendent $u$ ovom slučaju dorastao i snažan te se izglednije čini njegova mogućnost preživljavanja.

Iako se u citiranom fragmentu nadaje kako ne postoji mogućnost izvedbe protudokaza vezanog uz činjenično stanje, Trifonin već u idućem paragrafu vezanom za odlučivanje o mirazu naznačava mogućnost dokazivanja suprotnog (si non probatur) što je važno s aspekta postavljenih teza vezanih uz razumijevanje prirode instituta. Tako u pogledu miraznih dobara u izvoru stoji:

D. 34. 5. 9. 3. Tryphoninus libro 21 disputationum. Si maritus et uxor simul perierint, stipulatio de dote ex capitulo "si in matrimonio mulier decessisset" habebit locum, si non probatur illa superstes viro fuisse.

Ako muž i žena istovremeno umru, a donesena je odredba koja se odnosi na miraz, predviđajući da on treba pripadati mužu, ako je žena umrla tijekom braka, to će stupiti na snagu ako se ne dokaže da je nadživjela muža.

Prema tome, jasno je da ako bi žena nadživjela supruga, pitanje miraznih dobara bilo bi neupitno budući da je bilo moguće smatrati kako je brak raskinut muževljevom ranijom smrću. Prema tome, u situacijama kada nije moguće utvrditi činjenice, presumirana ranija smrt žene na osnovi njezina spola, ali uz jasno ostavljenu mogućnost izvođenja protudokaza.

U pogledu raspoređivanja miraznih dobara, značajan nam je i Papinijanov fragment, u kojem se presumira kako će majka nadživjeti dijete u slučaju brodoloma. U njemu stoji:

D. 23. 4. 26. Papinianus libro quarto responsorum pr. Inter socerum et generum convenit, ut, si filia mortua superstitem anniculum filium habuisset, dos ad virum pertineret: quod si vivente matre filius obisset, vir dotis portionem uxore in matrimonio defuncta retineret. Mulier naufragio cum anniculo filio periit. Quia verisimile videbatur ante matrem infantem perisse, virum partem dotis retinere placuit.

15 Kaser (n 13) 239; Renzo Lambertini, La problematica della commorienza nell' elaborazione giuridica romana (Giufre 1984) 48-49.

16 Lawrence Keppie, The Making of the Roman Army from Republic to Empire (Routledge 1998) 34; Martin Goodman, The Roman World $44 B C-A D 180$ (Routledge 1997) 113. 
Punac i zet se sporazumiju da će, u okolnostima kada je jednogodišnje muško dijete ostavljeno nakon smrti žene, miraz pripadati mužu; ako, međutim dijete umre za života svoje majke, onda muž može zadržati određeni dio miraza, pod uvjetom da je brak postojao u vrijeme smrti žene. Majka i dijete su umrli u brodolomu, a redoslijed smrti nije mogao biti naknadno utvrđen, svakom pravniku bi to izgledalo kao da je majka nadživjela dijete; stoga, muž može zadržati samo dio miraza.

Slijedom navedenog, možemo zaključiti kako se u okviru prvog koncepta ukazuje na nekoliko modela rješavanja danih situacija. Tako, u slučaju smrti ascendenata i descendenata u okviru istog nesretnog događaja, postavlja se presumpcija prema kojoj su dorasli descendenti nadživjeli ascendente, odnosno da su ascdenti nadživjeli svoje nedorasle descendente. Također, postavljena je i presumpcija prema kojoj se u slučaju istovremene smrti muža i žene ima smatrati kako je žena ranije umrla.

$S$ druge strane, promatrajući ove presumpcije isključivo u kontekstu razvoja rimskog prava, pojedini autori smatraju kako rimski pravnici uopće nisu imali u vidu vjerojatnost razmatranja danih događaja. ${ }^{17}$ Smatramo kako s ovakvim stavovima treba biti oprezan. Istina, primjetno je kako su katkad svoja mišljenja odnosno postavljene presumpcije opravdavali određenim carskim uredbama ${ }^{18}$ ili razlozima humanosti, ${ }^{19}$ no u određenim situacijama nema drukčijeg obrazloženja, osim da su uzimali u obzir opću snagu prosječnih pojedinaca u određenim životnim fazama. Pitanje opće snage pojedinaca potpuno je logično, ali nije u nužnoj korelaciji sa slijedom umiranja što će vjerojatno doprinijeti uočavanju potrebe odbacivanja ovakvog koncepta. U prilog odbacivanju ovako postavljene presumpcije idu i mišljenja suvremene medicinske znanosti. Naime, u medicini procjena točnog vremena smrti ovisi o mnoštvu čimbenika i u većini slučajeva teško je odrediti precizan trenutak smrti. Ovakve procijene ne mogu se generalizirati i moguće ih je promatrati isključivo in concreto. Iako starost sudionika može biti jedna od determinanti koja će utjecati na raniju ili kasniju smrt, ona ne mora prima facie biti odlučujuća za razvoj situacije. U pogledu pristupa samom vremenskom okviru medicinski stručnjaci razlikuju dvije varijante - trenutnu smrt i agonalno umiranje. Pravne činjenice vezane uz casum commorientem podvode se pod agonalno umiranje, koje uz određenu vjerojatnost podrazumijeva kako su različite osobe bile žive određeno kraće vrijeme nakon događaja koji je uzrokovao fatalne povrede. Iako kod agonalne smrti na tijelima osoba ostaju različite posljedice koje se mogu procijeniti u procesu obdukcije, ne postoji mogućnost precizne procjene o tome koji je od preminulih duže ili kraće agonalno umirao. Takvu procjenu nije moguće zasnovati niti na vjerojatnosti ako je riječ o manjim vremenskim intervalima što najčešće i biva slučaj kod agonalnog umiranja. ${ }^{20}$ Sukladno navedenom, postaje jasno kako ovakav pristup ne zadovoljava određenu dozu vjerojatnosti jer postavlja redoslijed koji nema uporište u znanosti, već je više produkt nagađanja ili humanog pristupa o vjerovanju da će primjerice sin nadživjeti oca (Usp. D. 34. 5. 22.). Kako smo i naglasili, rimski klasični pravnici situacije su

17 Tamás Nótári and Tekla Papp, "The problem of simultaneous death in the law of inheritance: historical and comparative approaches' [2013] 2 Fiat Iustitia 16.

18 Usp. supra Tryph. D. 34. 5. 9.1.

19 Usp. supra Iavol. D. 34. 5. 22.

20 Ovakav zaključak izveden je uz ekspertno mišljenje dr. sc. A. Salihbegovića, stalnog sudskog vještaka i docenta na Katedri za sudsku medicinu Medicinskog fakulteta Univerziteta u Sarajevu, zaprimljeno u pisanoj formi 13. listopada 2020. godine. Više o konceptu agonalnog umiranja u medicinskoj znanosti: Burkhard Madea (ed), Handbook of Forensic Medicine (Wiley Blackwell 2014) 49 et seq. 
nastojali posložiti u skladu s vjerojatnosti razmatranja danog događaja, odnosno u sumnji, posložiti situaciju na način koji im je djelovao najpravičnije. Ovakve presumpcije u pandektistici bit će predmet ozbiljnijih kritika. ${ }^{21}$ Pretpostavljamo kako je s vremenom došlo do spoznaje da ovako postavljen pristup ne zadovoljava elemente vjerojatnosti, što nužno označava kako nije ni pravično rješenje te zbog tih razloga u procesu razvoja europskog privatnog prava biva sve više napušten. O rješenjima koja će prevladati u europskom privatnom pravu pisat ćemo u nastavku.

\subsection{KONCEPT ISTOVREMENOSTI}

O drugom konceptu, utemeljenom na presumpciji istovremenosti, a koji će u konačnici prevladati u najvećem dijelu suvremenog prava, nailazimo na nekoliko mjesta u izvorima. Tako Marcijan piše:

D. 34. 5. 18. pr. Marcianus libro tertio regularum. In quibus casibus si pariter decesserint nec appareat, quis ante spiritum emisit, non videtur alter alteri supervixisse.

U slučajevima kada je više osoba zajedno umrlo, a ne utvrdi se tko je od njih prije umro, ne može se pretpostavljati tko je od njih koga nadživio.

Ovdje je jasna primjena koncepta istovremenosti, a onaj tko ima pravni interes, može dokazivati suprotno kroz svoj zahtjev shodno načelu onus probandi incumbit ei qui asserit. Drugi interesantan izvor, a na temelju kojeg je Romac prilagodio regulu o istovremenoj smrti više osoba jeste Trifoninov tekst iz D. 34. 5. 9. Prilagođena Romčeva regula glasi - non videtur alter alteri supervixisse cum simul decesserint (ne smatra se da je jedan nadživio drugog, ako su oba zajedno umrla). ${ }^{22}$ Ovakva regula prilagođena je iz ulomka izvornog teksta - et hic utrique, quia neutri eorum alter superstes fuit, ultimi primique obierunt. ${ }^{23} \mathrm{U}$ tekstu se obrađuje situacija $\mathrm{u}$ okviru koje čovjek koji ima dva maloljetna sina imenuje Ticija kao supstituta za onog sina koji umre drugi. Oba sina poginula su zajedno u brodolomu te se nameće pitanje čije imanje treba pripasti Ticiju? Ako su umrli jedan za drugim, onaj koji je kasnije umro, naslijedio bi imanje ranijeg pa bi Ticije došao do cjelokupne njihove imovine. Ipak, Ticije je imenovan kao zamjenski nasljednik samo za dijete koje kasnije umre. Polazeći od pretpostavke istovremene smrti, nije moguće smatrati da je itko od braće preživio pa se na tragu potonje citiranog Marcijanova

21 Usp. Vangerow (§ 33, prim 2); Savigny (II, 20-22); Windscheid (§ 53, prim 5); Wächter (I, 200). Detaljnije u: Carl Ludwig Arndts Riter von Arnesberg, Pandekte ili današnje rimsko pravo, vol 1 (A Đordević i DT Mijušković tr, Kraljevska srpska državna štamparija 1890) 39.

22 Ante Romac, Latinske pravne izreke (Globus 1982) 85.

23 D. 34. 5. 9. Tryphoninus libro 21 disputationum pr. Qui duos impuberes filios habebat, ei qui supremus moritur Titium substituit: duo impuberes simul in nave perierunt: quaesitum est, an substituto et cuius hereditas deferatur. Dixi, si ordine vita decessissent, priori mortuo frater ab intestato heres erit, posteriori substitutus: in ea tamen hereditate etiam ante defuncti filii habebit hereditatem. In proposita autem quaestione ubi simul perierunt, quia, cum neutri frater superstes fuit, quasi utrique ultimi decessisse sibi videantur? An vero neutri, quia comparatio posterioris decedentis ex facto prioris mortui sumitur? Sed superior sententia magis admittenda est, ut utrique heres sit: nam et qui unicum filium habet, si supremum morienti substituit, non videtur inutiliter substituisse: et proximus adgnatus intellegitur etiam qui solus est quique neminem antecedit: et hic utrique, quia neutri eorum alter superstes fuit, ultimi primique obierunt. 
fragmenta iz D. 34. 5. 18. treba smatrati da oni ne mogu međusobno naslijeđivati, pa tako ni supstitut ne bi mogao ostvariti pravo na nasljedni dio obojice braće. ${ }^{24}$

Usko s navedenim pitanjima povezan je i Ulpijanov fragment iz D. 24 1. 32. 14., koji se bavi valjanošću darivanja među zarobljenim osobama. S tim u vezi postavlja se pitanje na koji način regulirati situaciju u kojoj neprijatelj zarobi darovatelja i daroprimatelja ili ako obje strane umru u brodolomu ili požaru ili drugoj situaciji u kojoj nije moguće odrediti redoslijed smrti. ${ }^{25}$ U teoriji se pojavljuje nekoliko rješenja. Na primjer, može se smatrati kako će darovanje vrijediti samo u slučaju kada je daroprimatelj nadživio darovatelja, i to tek kada se daroprimatelj vrati. Takva situacija nije praktična, a i u suprotnosti je s načelom pravne sigurnosti. S druge strane, postoji mogućnost primjene fictio legis Corneliae, prema kojoj se rimski građanin koji padne u ropstvo ima smatrati umrlim u trenutku zarobljavanja, a sve kako bi se na taj način očuvala valjanost njegova darovanja. U ovoj situaciji smatrat će se kako nijedna osoba nije nadživjela drugu, a uzajamna darovanja bit će valjana te će darovanja pripasti u konačnici nasljednicima. Do sličnog zaključka, korištenjem drukčije argumentacije dolazi i Paulo u fragmentu D. 34. 5. 8. gdje daje mišljenje kako se darovanje između supružnika za slučaj smrti jednog od supružnika vraća darovatelju, no da u slučaju smrti u istom događaju treba smatrati darovanje valjanim budući da darovatelj svakako nema mogućnost potraživati imovinu jer nije živ. ${ }^{26}$ Slično zaključuje i Marcijan u D. 39. 6. 26. ${ }^{27}$

Ulpijanov fragment o valjanosti darivanja među zarobljenim osobama ocjenjujemo značajnim i kada je u pitanju određivanje vremena smrti osoba koje su odvedene u zarobljeništvo ili su nestale. Tako ako neprijatelj istovremeno zarobi dvije osobe, te one umru dok su bile u zarobljeništvu u različito vrijeme, nameće se pitanje mora li se uzeti u obzir datum kada su odvedene u zarobljeništvo kao datum smrti. Ovakav stav Ulpijan podržava, jasno navodeći da ako se stranke ne vrate, treba uzeti vrijeme kada su zarobljene kao vrijeme smrti - ubi non reverterunt, ut tempus spectandum sit captivitatis, quasi tunc defecerint, a u skladu s tim i dalje

24 Sličnu situaciju obrađuje i Papnijan. Usp. D. 28. 6. 42. Papinianus libro primo definitionum. Qui duos impuberes filios heredes reliquerat, ita substituit, si ambo mortui essent: deinde pueri post mortem patris simul perierunt: duae hereditates substituo deferuntur. Sed si diversis temporibus vita decedant, in hereditate novissimi pueri eius fratris, qui ante mortuus est, hereditatem substitutus inveniet: sed in ratione Falcidiae pueri prioris hereditas non veniet nec substitutus amplius quam Sescunciam iure testamenti desiderabit: legata quoque, quae a substituto eius filii data sunt, qui prior intestato decessit, ad irritum reccidunt.

25 D. 24. 1. 32. 14. Ulpianus libro 33 ad Sabinum. Si ambo ab hostibus capti sint et qui donavit et cui donatum est, quid dicimus? Et prius illud volo tractare. Oratio, si ante mors contigerit ei cui donatum est, nullius momenti donationem esse voluit: ergo si ambo decesserint quid dicemus, naufragio forte vel ruina vel incendio? Et si quidem possit apparere, quis ante spiritum posuit, expedita est quaestio: sin vero non appareat, difficilis quaestio est. Et magis puto donationem valuisse et his ex verbis orationis defendimus: ait enim oratio "si prior vita decesserit qui donatum accepit": non videtur autem prior vita decessisse qui donatum accepit, cum simul decesserint. Proinde rectissime dicetur utrasque donationes valere, si forte invicem donationibus factis simul decesserint, quia neuter alteri supervixerit, licet de commorientibus oratio non senserit: sed cum neuter alteri supervixerit, donationes mutuae valebunt: nam et circa mortis causa donationes mutuas id erat consequens dicere neutri datam condictionem: locupletes igitur heredes donationibus relinquent. Secundum haec si ambo ab hostibus simul capti sint amboque ibi decesserint non simul, utrum captivitatis spectamus tempus, ut dicamus donationes valere, quasi simul decesserint? An neutram, quia vivis eis finitum est matrimonium? An spectamus, uter prius decesserit, ut in eius persona non valeat donatio? An uter rediit, ut eius valeat? Mea tamen fert opinio, ubi non reverterunt, ut tempus spectandum sit captivitatis, quasi tunc defecerint: quod si alter redierit, eum videri supervixisse, quia redit.

D. 34. 5. 8. Paulus libro secundo sententiarum. Si inter virum et uxorem donatio facta fuerit, priore defuncto cui donatum est ad eum res redit qui donaverat: quod si simul tam is cui donatum est quam is qui donaverit, quaestionis decidendae gratia magis placuit valere donationem, eo maxime, quod donator non supervivat, qui rem condicere possit.

27 D. 39. 6. 26. Marcianus libro secundo regularum. Si qui invicem sibi mortis causa donaverunt pariter decesserunt, neutrius heres repetet, quia neuter alteri supervixit. Idem iuris est, si pariter maritus et uxor sibi donaverunt. Op. a. U radu G. Hamze uočili smo pogrešku vezanu uz navođenje predmetnog izvora. Usp. Gábor Hamza, 'Réflexions sur les présomptions relatives aux personnes décédées dans le même événement en droit romain’ (1993) 34 Annales Universitatis Scientiarum Budapestinensis de Rolando Eotvos Nominatae: Sectio Iuridica 22. 
postupati s darovanjem. Ovako postavljen koncept bit će značajan i u procesu razvoja suvremenog europskog privatnog prava.

\subsection{OPĆA ZAPAŽANJA}

Summa summarum, gore izloženi koncepti daju nam prostora da izvedemo još nekoliko općih zaključaka vezanih uz njihov razvoj. Prije svega, smatramo kako se iz analize izvora utemeljeno može istaknuti kako je rimsko pravo još od klasičnog razdoblja poznavalo oba koncepta. ${ }^{28} \mathrm{O}$ ovom pitanju u doktrini već su se vodile rasprave. Pojedini autori iznosili su argumente o tome kako izvori, koji su bili i predmet naše obrade, predstavljaju samo dokaze o primjeni općih dokaznih pravila u klasičnom razdoblju, ocjenjujući presumpcije kao interpolacije. ${ }^{29}$ Ipak, njihovi argumenti, a o čemu je detaljno pisala Radovčić, nisu u potpunosti bili zaokruženi i predstavljali su predmet različitih kritika. ${ }^{30} \mathrm{~S}$ tim u vezi, Radovčić se u doba izrade svoje analize pozivala kako je metodološki, onda kada nemamo sigurne i jasne dokaze o izvršenim interpolacijama, najznanstvenije vjerovati u tekstove vidljive u Justinijanovoj kodifikaciji. ${ }^{31}$ Rezultati novijih istraživanja potvrdit će ispravnost njezinih stavova, ali i na neki način doprinijeti jačanju teze kako su oba koncepta bila poznata i u klasičnom pravu. ${ }^{32}$

Nadalje, iz izvora se ne može zaključiti je li postojalo bilo kakvo isključivanje predstavljenih koncepata. Na tragu toga odabir primjene jednog ili drugog koncepta mogao je ovisiti o konkretnom casui comorienti. Tako je koncept istovremenosti, ako je suditi prema onome što je vidljivo u izvorima, bio primjenjivan u slučajevima komorijenata iz reda oslobođenika kako bi se zaštitio interes patrona, a vjerojatno i u nekim drugim situacijama kada bi ovakvo rješenja izgledalo prikladnije. ${ }^{33}$ Imajući u vidu težnje klasičnih rimskih pravnika, koji su konstantno težili usuglašavanju s načelom pravičnosti (aequitas), moguće je da je prvi koncept nailazio na širu uporabu jer bez medicinskih i praktičnih argumenata, on može djelovati pravičniji budući da slijedi niz zakonskog nasljednog reda u procesu rješavanja casus commorientis.

Uz pitanje primjene instituta komorijenata samo po sebi nameće se pitanje važenja koncepata u slučajevima kada između smrti osoba postoji određena prostorna ili vremenska udalje-

28 Dugo je u znanosti bila prihvaćena teza o tome kako klasično rimsko pravo nije imalo nikakve presumpcije vezane uz smrt više osoba u okviru istog događaja. Usp. Bertold Eisner i Marijan Horvat, Rimsko pravo (Nakladni zavod Hrvatske 1948) 105.

29 Ferrini većinu izvora objašnjava produktom općih pravnih principa, a za one kod kojih ne uočava prostor za primjenu općih pravnih principa naznačava kako je riječ o iznimnim situacijama u okviru kojih se ne može ocijeniti opće pravno stanje. Sumnju o klasičnom porijeklu elaborira iznoseći i argumente o različitosti načina izlaganja i stila u Gajevu fragmentu iz D. 34. 5. 23., dok u pogledu ostalih izvora priznaje nemogućnost objašnjavanja porijekla tekstova. Usp. Contardo Ferrini, Le presunzioni in diritto romano (Ermanno Loescher 1878) 34. Usp. (n 13).

31 Radovčić (n 3) 163.

32 Hanns Hohmann, 'Presumptions in Roman Legal Argumentation' in Hans V Hansen and others (eds), Argumentation and its Applications: Proceedings of the Ontario Society for the Study of Argumentation Conference - OSSA4 (Ontario Society for the Study of Argumentation 2001) 4; Fabrizio Macagno and Douglas Walton, 'Presumptions in Legal Argumentation' (2012) 25(3) Ratio Juris 271 et seq.

33 Op. a. Ostaje nejasno na temelju kojih izvora Radoman iznosi tvrdnju prema kojoj koncept istovremenosti dolazi u obzir u događajima koji su se "brzo i neodoljivo" odigrali - Radoman (n 5) 331. Smatramo kako brzina odigravanja samog događaja nije bitno obilježje u procesu određivanja koncepta koji bi mogao biti primijenjen. 
nost ili različit uzrok koji je doveo do smrtnih posljedica. Na temelju dosadašnjih zapažnja o ovom fenomenu, može se zaključiti kako izvori postavljaju uvjet uspostave veze između smrti dviju ili više osoba i određenog nesretnog događaja. Kao rezultat toga proizlazi kako smrt osoba mora biti prouzrokovana istim događajem ili šire promatrano, istom katastrofom.

U pandektistici nailazimo na podijeljene stavove o ovom pitanju. Pojedini autori, poput Kierulffa i Böckinga, smatrali su kako presumpcija o komorijentima može biti primijenjena u svakoj situaciji kada nije moguće sa sigurnošću utvrditi redoslijed smrti osoba, neovisno o tome je li smrt nastupila zbog zajedničke opasnosti. Zagovornici ovakvog pristupa toliko su široko tumačili mogućnost primjene da su kao primjer navodili slučaj u kojem dijete i otac iseljavaju u Ameriku i umiru bez ikakvih konkretnijih izvješća. S druge strane, takav pristup nisu podržali Vangerow, Savigny, Windscheid i Wächter. ${ }^{34}$ Oni su na ovo pitanje, prema našem mišljenju, gledali prerestriktivno, što će se u konačnici odraziti na rješenje u Njemačkom građanskom zakoniku (BGB), a o čemu će biti riječi u nastavku. ${ }^{35}$

U pogledu naznačenog mi smo na tragu pronalaska optimalnog rješenja, pri tome izbjegavajući krajnosti koje zagovaraju pojedini autori. Naime, iako smatramo kako pitanje zadovoljavanja kriterija "iste katastrofe" može biti predmetom šireg tumačenja, smatramo kako preširoko tumačenje autora poput Kierulffa i Böckinga nema uporište u rimskim pravnim izvorima. Kako smo ukazali, izvori jasno postavljaju uvjet uspostave određene veze između smrti dviju ili više osoba i određenog nesretnog događaja. S druge strane, restriktivni pristup, koji je zastupao Windscheid, a koji će u suvremenoj doktrini prihvatiti neki autori poput Hamze, iznoseći tvrdnju da se presumpcija ne može primjenjivati kada nije poznat konkretan uzrok koji je doveo do smrti osoba - nemaju potpuno utemeljenje. ${ }^{36}$ Ovdje je nužno biti otvoreniji i ostaviti prostora za primjenu i onda kada ne znamo konkretan uzrok smrti, ali znamo sa sigurnošću kako je smrt uzrokovana određenim događajem ili u vezi s istim, što proizilazi i iz rimskih pravnih izvora. Ovakav "srednji put" bit će nužan u razvoju instituta u europskom privatnom pravu, na što ćemo ukazivati i u nastavku rada.

\section{CASUS COMMORIENTES U POREDBENOJ PERSPEKTIVI ${ }^{37}$}

\subsection{CODE CIVIL (CC)}

U francuskoj pravnoj povijesti, slučajevi i rješenja vezana uz casus commorientes vidljivi su dosta prije donošenja Code civila (CC). Tako, Pariški parlament rješavajući pitanje smrti osoba u okviru masakra Svetog Bartolomea iz 1572. godine zaključuje kako su roditelji bili ubijeni prije djece jer su ih ubojice smatrali opasnijim. U izvorima je vidljiva i odluka iz 1629. godine vezana za slučaj utapanja majke i kćeri u rijeci Loari. Parlament je zaključio kako je dijete zbog

34 Usp. Kierulff (I, 92), Böcking (Inst. § 32, not 11), Vangerow (§ 33, prim 2), Savigny (II, 20-22), Windscheid (§ 53, prim 5), Wächter (I, 200). Detaljnije u: Arnesberg (n 21) 39.

35 Usp. (n 52).

36 Hamza (n 27) 28.

37 Op. a. Doprinos u prikupljanju pravnih izvora i njihovim prijevodima pružile su nam studentice Pravnog fakulteta u Sarajevu Ivana Žilić i Ena Muhić. Na trudu koje su uložile ovim putem im se iskreno zahvaljujemo. 
svoje dobi umrlo prije majke. Sudska odluka iz 1658. godine bavi se situacijom u kojoj su u okviru iste borbe ubijeni otac i sin, a kći se zaredila te otišla u samostan i time postala mrtva u smislu tadašnjeg civilnog prava. Sud je odlučio kako se u ovakvoj situaciji ima smatrati kako je sin sve nadživio. ${ }^{38}$

Donošenjem Code civila 1804. godine pitanje komorijenata riješeno je na tragu rimskog koncepta nadživjelosti pojedinih sudionika, uzimajući u obzir okolnosti slučaja, a ako ih nema, onda uzimajući u obzir kriterij dobi ili spola. ${ }^{39}$ Koncept je razrađen prema sljedećim kriterijima:

a) u slučaju smrti osoba starijih od 60 godina, pretpostavlja se da je najmlađi preživio;

b) u slučaju smrti osoba mlađih od 15 godina, pretpostavlja se da je najstariji preživio;

c) u slučaju smrti osoba između 15 i 60 godina, pretpostavlja se da je muškarac preživio, pod uvjetom da postoji razlika u dobi od najviše jedne godine;

d) u slučaju smrti osoba između 15 i 60 godina, gdje su svi muškarci ili žene, pretpostavlja se da je najmlađi preživio. ${ }^{40}$

$\mathrm{Na}$ temelju potonje raščlambe razvoja instituta u rimskom pravu vidljivo je kako predmetna rješenja nadahnuta rimskim pravnim izvorima, ali na njih je prirodno utjecaj ostavio povijesni razvoj i različiti autohtoni utjecaji francuske pravne doktrine i prakse. ${ }^{41}$ Pri razradi ovog koncepta francuski zakonodavac uzeo je fizičku sposobnost kao čimbenik preživljavanja. Cilj ovog pristupa bilo je logički razumjeti činjenično stanja. Ipak, iz današnje perspektive možemo slobodno ocijeniti kako je ovakav pristup bio neutemeljen. Na udaru kritike, osobito se našla presumpcija prema kojoj bi muškarac nadživio ženu. Slikovito to kritiziraju Hamza i Sajó, naglašavajući kako je potpuno jasno da u slučaju eksplozije zrakoplova neće postojati nikakva razlika u vjerojatnosti preživljavanja između muškarca i žene koji su sudjelovali u nesreći. ${ }^{42}$ Nadalje, rješenja su bila nedorečena pa ako bismo shematski posložili sve kombinacije na temelju propisanih kriterija, vidljivo je kako Code civil jasno predviđa samo četiri od šest mogućih situacija u vezi s primjenom uspostavljenih kriterija. Tako na primjer, iz njegovih odredbi nije vidljivo rješenje za situaciju u kojoj su u okviru istog događaja umrla dva komorijenta, od kojih je jedan između 15 i 60 godina starosti, a drugi iznad 60 godina starosti.

Ipak čini nam se kako je za proces primjene ovako postavljenih kriterija bila predviđena aktivnija uloga suda koji je trebao detaljno procijeniti okolnosti slučaja. Pravna praksa pokazuje, kako su u okviru francuskog prava predstavljene presumpcije od strane sudaca primjenjivane isključivo uz slobodno vrednovanje činjenica nesretnih događaja. Tako je u starijoj praksi vidljiva presuda Kasacijskog suda u Parizu od 21. travnja 1874. godine kojom odbija zahtjev za razmatranje presude Žalbenog suda u Rennesu, kojom su bile odbačene pravne presumpcije,

38 Linda Schoeman-Malan, 'Comparative Analysis of Commorientes: A South African Perspective: part I' (2017) 50(2) De Jure 46.

39 CC. $\$ 720$. Si plusieurs personnes respectivement appelées à la succession l’une de l'autre, périssent dans un mème événement, sans qu'on puisse reconnaître laquelle est décédée la première, la présomption de survie est determinée par les circonstances du fait, et, à leur défaut, par la force de l'àge ou du sexe.

CC. $§ 721$. Si ceux qui ont péri ensemble, avaient moins du quinze ans, le plus âgé sera présumé avoir survécu. S'ils étaient tous au dessus de soixante ans, le moins âgé sera présumé avoir survécu. Si les uns avaient moins de quinze ans, et les autres plus de soixante, les premiers seront présumés avoir survécu. CC. § 722. Si ceux qui ont péri ensemble, avaient quinze ans accomplis et moins de soixante, le màle est toujours présumé avoir survécu, lorsqu'il y a égalité d'âge, o si la différence qui existe n'excède pas une année. S'ils étaient du même sexe, la présomption de suivre quidonne ouverture à la succession dans l'ordre de la nature, doit être admise: ainsi le plus jeune est présumé avoir survécu au plus âgé.

41 Hamza (n 27) 28 
favorizirajući pretpostavke utemeljene na činjenicama u slučaju u kojem su majku i njezinu kćer morski valovi odnijeli u more, gdje je prema svjedočenjima bilo utvrđeno kako je majku, koja je stajala bliže provaliji, odnio prvi val, dok je tek drugi val odnio kćer. U predmetu pred Kasacijskim sudom od 21. siječnja 1960. godine, također je vidljivo kako su okolnosti konkretnog slučaja imale prednost nad presumpcijama. Navodi se kako je obitelj umrla tijekom bombardiranja, pri čemu su roditelji pronađeni zdrobljenih glava krhotinama, dok je tijelo njihova djeteta, gotovo bez ozljeda, dopuštalo izvođenje zaključka kako je smrt nastupila zbog fizičke iscrpljenosti, odnosno da je nastupila kasnije. ${ }^{43}$

Iz izloženih rješenja Code civila, a obraćanjem pozornosti na francuski izvornik, jasno je kako se presumpcije primjenjuju isključivo u slučaju istog događaja - un mème événement. Ekstenzivnim tumačenjem ovog izraza bit će zauzet stav kako se ovakvim događajem mogu smatrati i događaji koji su trajali duže vrijeme pa je smrt osoba potencijalno nastupila različitih kalendarskih dana, ali uz mogućnost izvođenja zaključka o tome kako je uzrok smrti (ili nestanka) povezan s konkretnim događajem.

Rješenja koncepta iz Code civila vezana uz komorijente recipirana su direktnim prijevodom ili uz manje izmjene na području Belgije, Nizozemske te dijelovima Njemačke tijekom 19. stoljeća. ${ }^{44}$ Procesom recepcije dospjet će i u pravne poretke Luisiane ${ }^{45}$ i dijelove Kanade. Ovakav koncept bit će recipiran i u Srpskom građanskom zakoniku. ${ }^{46}$

S druge strane, Austrijski građanski zakonik, a kasnije i Njemački i Švicarski, prihvatit će rimski koncept istovremenosti smrti koji je mnogo jednostavniji u primjeni. ${ }^{47}$ Takav koncept bit će prihvaćen i u talijanskom Codice civile, iako je općepoznato kako je na njega u najvećem dijelu utjecaj ostavio francuski Code civil. ${ }^{48}$ Slično, kao i većina autora koji su se bavili ovim pitanjem, podsjećamo kako smo bili izričiti još u procesu razrade koncepta istovremenosti u rimskom pravu te kako nam se isti čini praktičnijim i logički razumljivijim u situacijama kada nije moguće utvrditi točan redoslijed smrti. ${ }^{49}$

43 Elodie Creteau and Natalia Rostovtseva N, 'The Concept of Commorientes in French and Russian Inheritance Law' (2020) 8(1) Russian Law Journal 4, n 23.

44 L Roeleveld, 'Questions Concerning Simultaneous Death' [1970] Acta Juridica 38-42.

45 Vidi više: Monica Hof Wallace, 'A Primer on Absent Persons in Louisiana' (2018) 64(2) Loyola Law Review 423-40.

46 Op. a. Iako SGZ iz 1844. godine predstavlja u svom najvećem dijelu skraćeni prijevod OGZ-a, po pitanju komorijenata oslonjen je na Code civil i koncept nadživjelosti. Tako se u §52. navodi - ako su pak u jednovremenskoj opasnosti bili, onda se uzima da je mlađi starijega i muška glava žensku preživela, dokle se god suprotno ne dokaže. Ovakva odredba bila je predmet kritika različitih autora, kako zbog uporabe pojma "jednovremenost" tako i nepreciznosti zbog koje se u određenim situacijama ne može odrediti redoslijed smrti. Glede “jednovremenosti” ističe se kako uz takav izraz nema smisla postavljati presumpcije nadživjelosti budući da je jasno kako u jednovremenoj opasnosti komorijenti umiru u istom trenutku. Kad je riječ o nepreciznosti u svrhu kritiziranja, navodi se nemogućnost rješavanja situacije u kojoj su u okviru istog događaja život izgubili otac i kći, odnosno djed i unuka. Prema dobnom kriteriju uzet će se kako je kći nadživjela oca, a unuka djeda. Ako se uzme kriterij spola, onda će se uzeti kako je otac nadživio kćer, a djed unuku. Shodno navedenom vidljivo je kako je situacija neprecizno normirana i kako sudovi zbog ovako nepotpune regulacije mogu imati problem u procesu određenja mjerodavnog rješenja. Vidi više: Radoman (n 5) 333.

48 Codice civile pitanje komorijenata regulira primjenom koncepta istovremenosti. Tako u §924. stoji - se fra due o più chiamat rispettivamente a succedersi è dubbio quale abbia per primo cessato di vivere, che sostiene la morte anteriore dell' uno o dell'altro deve dare la prova; in mancanza di prova si presumono morti tutti ad un tempo, e non ha luogo trassmisione di diritto dall'uno all'altro. Usp. Codice civile del Regno d'Italia (Stamperia Reale 1865) (IT) 229. 
Zbog svoje kompleksnosti, ali i nedovoljnog djelovanja doktrine i prakse u cilju dodatne razrade samog koncepta, sustav razrađen u okviru Code civila, utemeljen na konceptu nadživjelosti, prestat će biti dijelom fracuskog pravnog poretka od 2001. godine, kada je i Francuska preuzela koncept istovremenosti..$^{50}$

\subsection{NJEMAČKI GRAĐANSKI ZAKONIK (BGB)}

U znanosti je općeprihvaćeno kako je Njemački građanski zakonik (njem. Bürgerliches Gesetzbuch) prema svom stilu i konceptima produkt učenja njemačke pandektističke škole. Prvi nacrt, na kojem se radilo od 1874. do 1888. godine, zbog brojnih kritika biva revidiran. Novi nacrt je 1895. godine odobren od strane Carskog savjeta, a godinu dana nakon toga dobio je i zakonsku snagu te se službeno počeo primjenjivati od 1. siječnja 1900. godine.

U okviru prvog nacrta BGB-a, koji je bio predmetom kritika, među ostalim i zbog prevelikog oslona na rimsko pravo, pitanje reguliranja komorijenata bilo je potpuno izostavljeno. Komisija je izostavljanje ovog pitanja opravdala besmislenim zasnivanjem "pozitivne intervencije" na nedostatnim presumpcijama koje bi nepotrebno stranke mogle direktno odvesti do rezultata koji bi se temeljili na prebacivanju tereta dokazivanja. ${ }^{51}$

U drugom nacrtu pitanje komorijenata biva riješeno u skladu s rimskim konceptom istovremenosti. Ono što se nametnulo kao dilema u procesu normiranja jest položaj norme unutar samog Zakonika. Naime, BGB je prema svojoj pandektističkoj strukturi podijeljen na pet knjiga - na uvodni (opći dio), obvezno, stvarno, obiteljsko i nasljedno pravo. Nedoumica je nastala u pogledu samog instituta komorijenata - regulira li on pitanje prestanka pravnog subjektiviteta kao opće pitanje ili je u pitanju isključivo pitanje vezano za nasljedno pravo. Komisija se opredijelila za prvo rješenje, odnosno reguliranje ovog instituta u općem dijelu. Tako u članku 20. BGB-a iz 1900. godine stoji ako je nekoliko osoba stradalo u zajedničkoj opasnosti, pretpostavlja se da su umrli u isto vrijeme. ${ }^{52}$ Primjetno je izričito zahtijevanje vezano uz zajedničku opasnost. Bez ulaska u dublju analizu, iz navedenog proizlazi nemogućnost primjene pravila o komorijentima u slučajevima kada postoji određena prostorna udaljenost ili različiti razlozi koji su doveli do smrtnih posljednica. Nije isključeno kako je na ovakvo (op. a. usko) rješenje imao utjecaja i osobno Windscheid, koji je zastupao užu primjenu fenomena komorijenata u odnosu na kriterij "iste katastrofe". ${ }^{33}$ Iako od 1874. godine nije bio član Komisije zbog povratka na Sveučilište u Leipzigu, smatramo kako njegov utjecaj na donošenje ovakve norme ne treba zanemariti, naročito uzimajući u obzir općepoznat ugled i doprinos koji je imao pri izradi Zakonika, kako kroz direktno djelovanje u prvoj Komisiji, tako i kroz dubinsko poznavanje pandektnog prava prezentirano u Lehrbuch des Pandektenrechts.

$50 \quad$ CC. (2001.) §725-1. Lorsque deux personnes, dont l'une avait vocation à succéder à l'autre, périssent dans un même événement, l'ordre des décès est établi par tous moyens. Si cet ordre ne peut être déterminé, la succession de chacune d'elles est dévolue sans que l'autre y soit appelée. Toutefois, si l'un des codécédés laisse des descendants, ceux-ci peuvent représenter leur auteur dans la succession de l'autre lorsque la représentation est admise.

51 Benno Mugdan, Die gesammten Materialien zum Bürgerlichen Gesetzbuch für das Deutsche Reich, vol 1 (Decker 1899) 374.

52 Das Bürgerliche Gesetzbuch (1 Fassung - Reichsgesetzblatt 1896, ausgegeben am 24. 08. 1896, in Kraft seit 01. 01. 1900) (DE) $\S 20$ Sind Mehrere in einer gemeinsamen Gefahr umgekommen, so wird vermuthet, daß sie gleichzeitig gestorben seien. 
Sasvim prirodno kao reakcija na usko promatranje "iste katastrofe", u njemačkoj pravnoj doktrini javili su se autori koji su zastupali tezu kako pojam zajedničke opasnosti (njem. einer gemeinsamen Gefahr) ne bi trebalo tumačiti preusko. ${ }^{54}$ Pojedini autori detaljnije su razmatrali neke slučajeve za koje nije u potpunosti jasno mogu li se podvesti pod koncept zajedničke opasnosti. Tako Regelsberger iznosi stav prema kojem se koncept istovremenosti, u slučaju smrti uzrokovanih zajedničkom opasnošću, ne može primijeniti kod smrti majke i djeteta tijekom poroda ili smrti dviju osoba u okviru iste epidemije. Paralelno s tim, prirodno se nametalo pitanje koliko je takav pristup isključenja određenih slučajeva kakvi su navedeni u skladu s temeljnim načelom pravičnosti. ${ }^{55}$

Donošenjem Zakona o nestanku, proglašenju smrti i određivanju vremena smrti od 4. srpnja 1939. godine (njem. Gesetz über die Verschollenheit, die Todeserklärung und die Feststellung der Todeszeit) članci 13. - 20. BGB-a gube pravnu snagu. Novi Zakon u članku 11. propisuje ako se ne može dokazati da je od nekoliko umrlih ili proglašenih umrlim jedna osoba nadživjela drugu, pretpostavlja se da su umrli u isto vrijeme. ${ }^{56}$ Jasno je kako se u okviru navedenog članka ne gleda toliko restriktivno u odnosu na postojanje zajedničke opasnosti i kako se ovakvo rješenje čini adekvatnijim za primjenu u svim situacijama gdje nije moguće dokazati redoslijed smrti osoba u položaju relevantnom za nasljedno pravo.

Kako smo potonje spomenuli, slično, jednostavno rješenje, bit će recipirano i u Švicarskom građanskom zakoniku, usvojenom 1907. godine. On se u pogledu normiranja pitanja komorijenata oslanja na koncept istovremenosti, tada prihvaćen u njemačkom pravu. Za razliku od njemačkog prava, koje je u početku uvjetovalo primjenu instituta postojanjem zajedničke opasnosti, Švicarski građanski zakonik to će pitanje regulirati manje restriktivno. Tako, u članku 32., stavak 2. Zakonika stoji da ako se ne može dokazati koja je od više osoba nadživjela drugu, smatra se da su istovremeno umrle. ${ }^{57}$

\subsection{AUSTRIJSKI OPĆI GRAĐANSKI ZAKONIK (OGZ)}

Metodološka paradigma u našim istraživanjima često je ukazivanje na mogućnost poboljšanja "pozitivnog" privatnopravnog sustava primjenom pravičnih načela rimske pravne tradicije kao temelja privatnopravnog sustava u Europi. Imajući u vidu takav pristup, posebnu pozornost u pravilu posvećujemo Austrijskom općem građanskom zakoniku (njem. Allgemeines bürgerliches Gesetzbuch) s pomoću kojeg je rimska pravna tradicija postavila snažne temelje razvoju privatnog prava na našem području. ${ }^{58}$ Upravo zbog tog razloga, rješenja OGZ-a analiziramo na posljednjem mjestu, povezujući njegovu primjenu s danas aktualnim pitanjima.

54 Usp. Gottlieb Planck, Planck’s Kommentar zum Bürgerlichen Gesetzbuch, vol 1 (De Gruyter 1913) § 20, 1.

55 Ferdinand Regelsberger, Pandekten (Duncker \& Humbolt 1893) §61, 5.

56 Verschollenheitsgesetz $§ 11$. Kann nicht bewiesen werden, daß von mehreren gestorbenen oder für tot erklärten Menschen der eine den anderen überlebt hat, so wird vermutet, daß sie gleichzeitig gestorben sind.

57 Codice Civile Svizzero (1907) §32, 2. Se non può essere fornita la prova che di più persone una sia sopravvissuta all'altra, si ritengono morte simultaneamente.

58 O ulozi OGZ-a u izradnji pravne kulture u Hrvatskoj: Tatjana Josipović, '200 Jahre der ABGB-Anwendung in Kroatien - 135 Jahre als Gesetz und 65 Jahre als "Rechtsregeln"' in Constanze Fischer-Czermak and others (eds), Festschrift 200 Jahre ABGB (Manz Verlag 2011) 157-74; Nikola Gavella, ‘Građansko pravo u Hrvatskoj i kontinentalnoeuropski pravni krug: u povodu 
U pogledu komorijenata OGZ prvi u modernom europskom pravu ovo pitanje rješava primjenom rimskog koncepta istovremenosti. ${ }^{59} \mathrm{U}$ izvorniku iz 1811. godine, u članku 25. stoji da kada je dvojba, koja je od dvije ili više pokojnih osoba prije preminula, mora onaj, koji tvrdi da se smrt jednoga prije dogodila nego drugoga, to dokazati; ako on to dokazati ne može, uzima se da su svi u isto doba umrli, i o prijenosu prava s jednoga na drugoga govoriti se ne može. ${ }^{60}$

Jasno je dakle, ako se ne može sa sigurnošću utvrditi tko je ranije, odnosno kasnije umro, teret dokazivanja (onus probandi), pada na onoga tko to tvrdi, a u slučaju nemogućnosti izvedbe dokaza o točnom redoslijedu smrti, smatrat će se kako je smrt nastupila istovremeno. Problem je što u predmetnoj odredbi istovremenost nije nedvosmisleno presumirana. Detaljnije obraćajući pozornost na predmetnu odredbu, vidljivo je kako se koncept istovremenosti primjenuje, tek ako on (op. a. zainteresirani) to ne može dokazati (njem. kann er dieses nicht). Iz ovoga slijedi kako sudu nije ostavljena mogućnost direktnog postupanja, već je nužno pokušati dokazati raniju ili kasniju smrt, pa tek u slučaju nemogućnosti dokazivanja primijeniti presumpciju istovremenosti. U Kirchstetterovu komentaru OGZ-a stoji kako austrijsko pravo negira koncept nadživjelosti te onaj tko tvrdi da je određena osoba umrla prije druge, tu tvrdnju mora dokazati, a ne uspije li je dokazati, onda se pretpostavlja istovremenost smrti. ${ }^{61}$ Prema tome, a simili ad smile ako netko uvjetuje neko pravo činjenicom da je smrt nastupila istovremeno, dužan je to dokazati. U svakom konkretnom slučaju, ovisno o zahtjevu osoba koje imaju određeni pravni interes, utvrđuje se redoslijed smrti ili se podrazumijeva istovremenost smrti dvije ili više osoba. Iz drugih pravnih akata iz razdoblja Austro-Ugarske Monarhije vidljivo je također kako je postojala mogućnost obaranje presumpcije vezane uz proglašenje smrti ili vremena proglašenja određene osobe umrlom. Naime, vjerojatno je zbog situacije izazvane Prvim svjetskim ratom u Zakonu o proglašenju smrti i dokazivanju smrti iz 1918. godine, uz ostale izmjene, dodan i članak 10.a u kojem stoji ako odsutna osoba poslije proglašenja smrti još živi ili ako je umrla u drugi dan, a ne u presumptivni dan smrti, može osoba, koja je proglašena mrtvom, ili tko inače ima pravnog interesa za ukinuće ili ispravak proglašenja smrti (...) predložiti kod suda, koji je izrekao proglašenje smrti u prvom stepenu, da se ukine ili ispravi proglašenje smrti. ${ }^{62}$ Iz ovakve odredbe jasno je kako i osobe koje imaju određeni pravni interes mogu pobijati i činjenice vezane uz vrijeme smrti, ako je ono utvrđeno primjenom presumpcije iz članka 25. OGZ-a, dokazujući pri tome redoslijed smrti ili istovremenost smrti sudionika nesretnog događaja.

140. godišnjice stupanja na snagu OGZ u Hrvatskoj' (1993) 43(4) Zbornik Pravnog fakulteta u Zagrebu 335-40; u Bosni i Hercegovini: Meliha Povlakić, 'Der mehr als einhundertjährige Einfluss des ABGB in Bosnien und Herzegowina' in Constanze Fischer-Czermak and others (eds), Festschrift 200 Jahre ABGB (Manz Verlag 2011) 223-52; Mehmed Bećić, 'Historijska i pravna osnovanost primjene Općeg građanskog zakonika u BiH nakon okupacije 1878. godine' [2011] 54 Godišnjak Pravnog fakulteta u Sarajevu 63-79. O mogućnostima direktne i analogne primjene rimskog prava primjenom članka 7. OGZ-a: Marko Petrak, 'Rimsko pravo kao pozitivno pravo u Republici Hrvatskoj: prilog tumačenju Zakona o načinu primjene pravnih propisa donesenih prije 6. travnja 1941. godine' (2006) 6(10) Hrvatska pravna revija 1-11; Mirza Hebib, 'Razvoj pogrebnog prava u rimskoj pravnoj tradiciji' (2020) 57(3) Zbornik radova Pravnog fakulteta u Splitu 865-67.

59 Usp. D. 34. 5. 18. pr. Marcianus libro tertio regularum. Op. a. Katkad u literaturi ovaj koncept nazivaju i "austrijskim”. Mi ćemo ga ipak nazivati rimskim, što nam djeluje preciznije imajući u vidu citirani izvor.

60 Allgemeines bürgerliches Gesetzbuch (1811) § 25. Im Zweifel, welche von zwei oder mehreren verstorbenen Personen zuerst mit Tode abgegangen sei, muss derjenige, welcher den früheren Todesfall des einen oder des andern behauptet, seine Behauptung beweisen; kann er dieses nicht, so werden alle als zu gleicher Zeit verstorben vermutet, und es kann von Übertragung der Rechte des einen auf den andern keine Rede sein.

61 Ludwig Kirchstetter, Commentar zum Oesterreichischen Allgemeinen bürgerlichen Gesetzbuche mit vorzüglicher Berücksichtigung des gemeinen deutschen Privatrechts (Brockhaus 1876) § 25.

62 Zakon od 31. marta 1918. kojim se mijenja zakon od 16. februara 1883. o postupku u svrhu proglašenja smrti i dokazivanja smrti, dostupno (Lista državnih zakona kraljevine i zemlje zastupane u carevinskom vijeću, vol 61, 1918) 339-40. 
Sustavnom tumačenju moramo pribjeći i u pogledu pitanja zadovoljavanja kriterija "iste katastrofe”. Naime, iz članka 25. OGZ-a, ali i komentara na isti, ne proizlazi potpuno raščlanjenje. No, obratimo li pozoronost na članak 24. kojim je regulirano pitanje proglašenja nestale osobe umrlom, uočit ćemo kako se kao kriterij javlja bliska smrtna opasnost (njem. oder in einer anderen nahen Todesgefahr), uz navođenje primjera brodoloma ili rata. ${ }^{63}$ Imajući u vidu da takvi slučajevi imaju jasnu korelaciju s izvorima rimskog prava iz kojih crpimo pravila o postupanju u casui commorienti, potpuno slobodno uspostavljamo logičku vezu u pogledu primjene članaka 25. S tim u vezi, smatramo kako OGZ ostavlja dovoljno širok prostor za njegovu primjenu i onda kada ne znamo konkretan uzrok smrti, ali sa sigurnošću znamo kako je smrt nastala uzrokovana određenim događajem ili u vezi s istim.

Ipak, u austrijskom pravu doći će do određenih pojednostavnjenja tijekom 20. stoljeća. Članak 25. OGZ-a bit će zamijenjen u doba Anschlussa. ${ }^{64}$ Donošenjem ranije spomenutog njemačkog Verschollenheitsgesetza iz 1939. godine, i na području Austrije na snagu će stupiti jednostavnija formulacija koncepta istovremenosti. ${ }^{65}$ Donošenjem austrijskog Zakona o proglašenju smrti (njem. Todeserklärungsgesetz) iz 1950. godine članci 1. - 11. bit će u potpunosti preuzeti iz Verschollenheitsgesetza. ${ }^{66} \mathrm{U}$ konačnici moramo naglasiti, kako će prednost ovakve odredbe u odnosu na članak 25. OGZ-a biti nedvosmisleno (bez potrebe tumačenja) širenje primjene na smrti nastale u vezi s nekim događajem, što je odista važno u slučajevima poput nestanka osoba za vrijeme rata, ali i skidanje najvećeg tereta sa zainteresiranih osoba koje su člankom 25. OGZ-a bile obvezne dokazivati redoslijed smrti u svrhu mogućnosti primjene presumpcije istovremenosti.

\subsubsection{UTJECAJ NA PODRUČJU JUŽNE MONARHIJE}

U razdoblju pravnog partikularizma nakon 1918. godine, u okviru slovensko-dalmatinskog, hrvatsko-slavonskog i bosanskohercegovačkog pravnog područja ostat će u primjeni članak 25. OGZ-a kao osnova reguliranja pitanja komorijenata ${ }^{67}$ Općepoznato je kako pokušaji kodificiranja građanskog prava u razdoblju Kraljevine nisu urodili plodom, iako se na tome radilo i u okviru pravničke zajednice intenzivno raspravljalo. Pregledom Predosnova građan-

63 Allgemeines bürgerliches Gesetzbuch (1811) § 24. Wenn ein Zweifel entsteht, ob ein Abwesender oder Vermisster noch am Leben sei oder nicht, so wird sein Tod nur unter folgenden Umständen vermutet: (1) wenn seit seiner Geburt ein Zeitraum von 80 Jahren verstrichen und der Ort seines Aufenthaltes seit zehn Jahren unbekannt geblieben ist; (2) ohne Rücksicht auf den Zeitraum von seiner Geburt, wenn er durch 30 volle Jahre unbekannt geblieben; (3) wenn er im Kriege schwer verwundet worden oder wenn er auf einem Schiffe, da es scheiterte, oder in einer anderen nahen Todesgefahr gewesen ist und seit der Zeit durch drei Jahre vermisst wird. In allen diesen Fällen kann die Todeserklärung angesucht und unter den (\$277) bestimmten Vorsichten vorgenommen werden.

64 Op. a. Anschluss je naziv za pripajanje Austrije Njemačkoj koje je izvršeno u ožujku 1938. Austrija će ponovno svoju samostalnost ostvariti nakon 1945. godine.

65 Usp. (n 56).

66 Todeserklärungsgesetz (BGBI 23/1951), bilj § 1-11 des Gesetzes über die Verschollenheit, die Todeserklärung und die Feststellung der Todeszeit vom 4 Juli 1939, Deutsches RGBI. I S. 1186 (DE).

67 Na području Međimurja, Baranje, Bačke i Banata, koji su do 1918. godine bili dio Ugarske, ostat će u primjeni Tripartit, propisi Ugarskog sabora i vlade te načelne odluke Kurije u Budimpešti. S tim u vezi interesantno je naznačiti kako su ugarski propisi bili nekonzistentni po pitanju reguliranja komorijenata. Tako je u Zakonu o općem privatnom pravu B. Horvatha iz 1871. godine bila predviđena oboriva presumpcija istovremene smrti. U kasnijim varijantama Nacrta građanskog zakonika (1900., 1913., 1914. 1916. i 1928. godine) doći će do izmjena, a konačni, ujedno i najznačajniji Nacrt u potpunosti će isključiti presumpcije navodeći $\mathrm{da}$ - ukoliko je više osoba u zajedničkoj opasnosti zajedno umrlo, ne može biti pretpostavke o tome koja je od njih prije umrla, niti o tome da su u isto vrijeme umrle. Usp. Nótári (n 17) 20; Radoman (n 5) 332. 
skog zakonika Kraljevine Jugoslavije, vidljivo je kako je u pogledu pitanja komorijenata bilo planirano inkorporiranje koncepta istovremenosti prema uzoru na članak 25. OGZ-a. U okviru predloženog članka 38. Predosnova stajalo je da ako se ne može dokazati da je jedno od više umrlih lica nadživjelo drugo, onda se uzima da su umrla u isto vrijeme. ${ }^{68}$ Da je kojim slučajem došlo do usvajanja Predosnova, ovakav pristup bio bi u svakom slučaju progresivan iskorak budući da je riječ o pravnom kontinuitetu koji se ogledao u prilagodbi članka 25. OGZ-a i konceptu koji je već bio u primjeni u velikom dijelu Kraljevine, a koji je ujedno mnogo logičniji i praktičniji u odnosu na rješenje kakvo je tada na primjer imao SGZ koji se primjenjivao u određenim pravnim područjima tadašnje države. ${ }^{69}$

U poslijeratnom razdoblju ni socijalistički nasljednopravni okvir ne regulira pitanje komorijenata. ${ }^{70}$ Također, ni propisi o proglašenju nestale osobe umrlom i dokazivanju smrti neće urediti ova pitanja. ${ }^{71}$ Shodno navedenom, primjenjivat će se pravna pravila OGZ-a sukladno odredbama Zakona o nevažnosti pravnih propisa donesenih prije 6. travnja 1941. godine i za vrijeme neprijateljske okupacije. ${ }^{72} \mathrm{U}$ opsežnom Komentaru zakona o nasljeđivanju FNRJ jasno stoji kako u casibus commorientibus treba primijeniti članak 25. OGZ-a te ako nije moguće utvrditi koja je od osoba umrla ranije, treba uzeti da su obje, ili više njih, umrle u isti čas, pa između njih nema nasljeđivanja. ${ }^{73}$

U svom udžbeniku nasljednog prava Blagojević, ispravno, detaljnijom analizom članka 25. OGZ-a zaključuje kako se koncept istovremenosti treba supsidijarno primjenjivati i to na način da sudovi u svakom slučaju trebaju pokušati utvrditi redoslijed smrti u okviru istovremene zajedničke opasnosti. Zaključuje kako tek kada nije moguće utvrditi redoslijed smrti, treba primijeniti presumpciju o istovremenoj smrti dvaju ili više osoba koje se nalaze u položaju relevantnom za nasljedno pravo. ${ }^{74}$ Ono što on ne naglašava, a o čemu smo ranije pisali i što je u direktnoj vezi s izloženim, jest kako sud u primjeni ove odredbe mora postupati prema zahtjevima osoba koje imaju određeni pravni interes, u vezi s utvrđivanjem redoslijeda umrlih ili primjene koncepta istovremenosti.

U procesu analiziranja tendencija u ovom razdoblju osobitu pozornost zaokuplja Radmanov stav iz 1958. godine kojim predlaže de lege ferenda usvajanje kocepta nadživjelosti prema kojem bi pri nejednakoj starosti komorijenata koji su nestali u istoj životnoj opasnosti važila pretpostavka da je mlađa osoba nadživjela stariju bez obzira na spol jer to odgovara principu nasljeđivanja po nasljednim redovima. ${ }^{75}$ Smatramo kako je ovakav stav potpuno pogrešan. Kako smo već obrazložili takav pristup nije ni praktičan, ni logičan, niti ima utemeljenje u vjerojatnosti odvijanja nesretnog događaja. Komparativno promatrajući, vidjeli smo kako će

68 Vesna Radovčić, 'Pokušaj kodifikacije građanskog prava u staroj Jugoslaviji (Predosnova građanskog zakonika za Kraljevinu Jugoslaviju)' (1975) 7(1) Radovi 267.

69 Usp. (n 46).

70 Zakon o nasljeđivanju FNRJ (SL 20/1955) (YU)

71 Zakon o proglašenju nestalih osoba za umrle i o dokazivanju smrti (SL 24/1952, 26/1952) (YU)

72 Zakon o nevažnosti pravnih propisa donesenih prije 6. travnja 1941. godine i za vrijeme neprijateljske okupacije (SL 86/1946) (YU)

73 Milan Kreč i Đuro Pavić, Komentar Zakona o nasljeđivanju (Narodne novine 1964) 411.

74 Borislav Blagojević, Nasledno pravo FNRJ (Naučna knjiga 1955) 42-43. 
takav koncept napustiti, doduše nakon velikog vremenskog odmaka, i Francuska, koja ga je prva uz određene modifikacije inkorporirala u svoj poredak. Ipak, Radoman će u kasnijem radu biti oprezniji s prijedlozima u pogledu de lege ferenda uređenja. Može se reći da ih neće ni iskazati, već zaključno navodi kako se ne želi upuštati u pitanje koja je od dvije predmnjeve slučaja komorijenata gipkija i praktičnija za suvremeno pravo. ${ }^{76}$

\subsubsection{PRAVNI KONTINUITET I PRAKTIČNE REPERKUSIJE U VEZI S PRIMJENOM KONCEPTA ISTOVREMENOSTI}

Trenutak smrti predstavlja pravno relevantnu činjenicu u procesu nasljeđivanja. Uz iznimku nasciturusa, sposobnost za nasljeđivanje ima samo osoba koja je živa u trenutku otvaranja nasljedstva. Prema tome, jasno je kako nezadobiveno nasljedstvo ne može biti preneseno na nasljednikove nasljednike. Zbog toga je potpuno jasno kako način reguliranja casuum commorientium u okviru pravnog poretka ima naročito praktične reperkusije i može uveliko utjecati na način podjele ostavinske mase. ${ }^{77}$

Suvremeno nasljednopravno zakonodavstvo u Republici Hrvatskoj i Bosni i Hercegovini pitanje komorijenata regulira primjenom rimskog koncepta istovremenosti. Oslanjanje na ovaj koncept rezultat je pravnog kontinuiteta u odnosu na potonje rješenje iz OGZ-a. Zakoni o nasljeđivanju u Republici Hrvatskoj i Federaciji BiH imaju potpuno identičnu normu i okviru iste stoji ako su dvije ili više osoba izgubile život u istom događaju, smatrat će se da ni jedna od njih nije bila živa u trenutku otvaranja nasljedstva druge, ako se ne dokaže suprotno. ${ }^{78} \mathrm{U}$ bosanskohercegovačkom entitetu Republika Srpska ovo pitanje nije regulirano te se pitanje komorijenata rješava primjenom pravnog pravila sadržanog u članku 25. OGZ-a, a sukladno odredbama Zakona o nevažnosti pravnih propisa donesenih prije 6. travnja 1941. godine i za vrijeme neprijateljske okupacije. ${ }^{79}$

76 Radoman (n 5) 334.

77 U procesu izrade ovog rada, u razdoblju od rujna do prosinca 2020. godine, proveli smo istraživanje sudske prakse na području Bosne i Hercegovine. Preko elektroničke pošte zatražili smo od 15 općinskih/osnovnih sudova i svih javnobilježničkih ureda (preko nadležnih komora) da nam dostave podatke o primjeni instituta komorijenata i izazovima s kojima su se u svom radu suočili. U okviru najvećeg broja zaprimljenih odgovora, od čega je 5/7 (71,42\%) odgovora od nadležnih sudova i 10/11 (90,9\%) odgovora iz javnobilježničkih ureda, ukupno 15/18 (83,33\%), konstatirano je kako se s primjenom instituta nisu dosad susretali. U odgovorima u okviru kojih je konstatirana primjena instituta nije iskazan bilo kakav izazov. Detaljnijim pregledom sudske prakse (103 dostupna predmeta u okviru kojih je raspravljana ostavina više umrlih osoba u položaju relevantnom za nasljedno pravo) koji nam je omogućen susretljivošću sutkinje Irme Boračić-Šuman s Općinskog suda u Sarajevu, nije utvrđena primjena instituta komorijenata, izuzevši jedan recentan predmet (br. O 719858), u okviru kojeg se institut navodi, bez poziva na relevantnu zakonsku odredbu. U okviru istog zbog kontradiktornih izjava, vezanih uz smrt supružnika S. M. i N. D. iz Sarajeva, Sud konstatira istovremenost smrti i u skladu s tim zaključuje kako nema međusobnog nasljeđivanja. U činjeničnom stanju navedeno je kako su supružnici za vrijeme međunarodnog oružanog sukoba u BiH, bili nastanjeni u Sarajevu, u okupiranom naselju Grbavica, gdje su poginuli od eksplozije granate 14. lipnja 1992. godine, ispred ulaza u zgradu u kojoj su stanovali. Sud je ranije prihvatio izjave svjedoka S. F. i N. F., susjeda preminulih, koji su čuli pozive u pomoć neposredno nakon eksplozije i svjedočili kako je supruga (N. D.) pogođena u glavu ležala ne dajući znakove života, dok je suprug (S. M.) teško ranjen u noge i grudni koš, na trenutak bio svjestan, zatim ostao bez svijesti te je u konačnici odvezen u bolnicu u Lukavici gdje je prema izjavama trećih osoba, koja su u to vrijeme mogle boraviti na tom području, preminuo i pokopan na groblju u Lukavici. Poslije su se pojavile izjave prema kojima je supruga preminula kasnije. Imajući u vidu naznačene kontradiktornosti, Sud je primijenio institut komorijenata.

78 U Republici Hrvatskoj - čl. 124., st. 4. Zakona o nasljeđivanju (NN 48/2003, 163/2003, 35/2005, 127/2013, 33/2015, 14/2019) (HR); u Federaciji BiH - čl. 157., st. 4. Zakona o nasljeđivanju u FBiH (SN 80/2014 i 32/2019 - odluka US) (BA).

79 Zakon o nasljeđivanju Republike Srpske (SG 1/2009, 55/2009 - ispr 91/2016, 28/2019 - odluka US i 82/2019) (BA). Op. a. U okviru Zakona postoji članak kojim se uređuje "Sposobnost za nasljeđivanje" (čl. 148.), gdje je regulirano kako nasljednik mora biti živ u trenutku otvaranja nasljedstva, zatim je postavljena fikcija o nerođenom djetetu i naznačena mogućnost da se 
Na tragu naznačenih odredbi, sustavno promatrajući, kad je riječ o nezadobivenom nasljedstvu, jasno je da, ako oporučni nasljednik umre prije ostavitelja, njegovi nasljednici ne mogu polagati nikakvo pravo u odnosu na ostavinu koju bi on oporučno naslijedio da je ostao živ. S druge strane, u okviru zakonskog nasljeđivanja postoji iznimka. Naime, od krvnih srodnika ostavitelja u krugu njegovih zakonskih nasljednika nalaze se svi njegovi srodnici iz vertikalne linije - potomci (descendenti) te preci (ascendenti). Iz horizontalne linije tu su pobočni srodnici (kolaterali) koji su potomci ostaviteljevih roditelja ili djedova i baka. Uz njih se kao zakonski nasljednik pojavljuje i bračni (ili izvanbračni) drug. Opće pravilo koje će se primjenjivati i među nasljednicima ostavitelja jest da oni ne mogu polagati nikakvo pravo u odnosu na ostavinu koju bi on naslijedio da je ostao živ. Jedina iznimka bit će s njegovim descendentima gdje će prema načelu reprezentacije (ius representationis) potencijalnog zakonskog nasljednika koji nije naslijedio, naslijediti njegovi potomci. Praktično promatrajući, ako su iza ostavitelja koji je stradao zajedno sa sinom u okviru iste katastrofe ostali supruga, kći i sinovljeva supruga, uzmemo li u obzir da su ostavitelj i sin stradali u isto vrijeme i da među njima nije došlo do nasljeđivanja, sva ostaviteljeva imovina pripast će njegovoj supruzi i kćeri. Sinovljeva supruga neće polagati nikakvo pravo u odnosu na imovinu njezina supruga. S druge strane, ako je u istoj situaciji, iza sina uz suprugu ostalo i dijete (ostaviteljev unuk), ono će imati pravo participirati u imovini ostavitelja prema načelu reprezentacije te će imovina biti podijeljena između supruge, kćeri i sinovljeva sina (unuka ostavitelja). Ovakvo rješenje u suvremenom pravu predstavlja pravni kontinuitet u odnosu na odredbu 733. OGZ-a. ${ }^{80}$ Iako su u ranija vremena postojale određene nejasnoće vezane uz doktrinarno razumijevanje položaja nasljednika koji nasljeđuju prema principu reprezentacije, one nisu utjecale niti dovodile u pitanje njihov položaj u procesu primjene instituta komorijenata i koncepta istovremenosti. Te dileme prvenstveno su se ticale pitanja nasljeđuju li ovakvi nasljednici pri primjeni načela reprezentacije svog pretka na temelju zakona zbog toga što su ostaviteljevi srodnici (iure proprio) ili prema pravnom temelju koji je imao njihov predak kojeg oni predstavljaju (alieni iuris). ${ }^{81} \mathrm{U}$ povijesnoj perspektivi pojedini autori smatraju kako je do ovakvih nejasnoća dolazilo zbog nerazumijevanja i pogrešnog interpretiranja Novellae 118. kojom je u europskoj pravnoj povijesti i konstituirano načelo reprezentacije. ${ }^{82}$ Suvremena nasljednopravna znanost kod ovih pitanja je konzistentna. Tezu o vlastitu temelju u odnosu na ostavitelja potvrdit će i raščlamba situacije vezane uz nedostojnost, gdje će nedvosmisleno biti zaključeno kako ni nedostojnost ne smeta potomcima nedostojnog da naslijede ostavitelja. ${ }^{83}$

pravna osoba pojavi kao nasljednik. Ovakav članak sličan je čl. 3. Zakon o nasleđivanju Republike Srbije (SG 46/95, 101/2003 odluka USRS i 6/2015) (RS) koji također nije regulirao pitanje komorijenata. U slučaju da zakonodavac u Republici Srpskoj odluči normirati ovo pitanje nomotehnički bi bilo potrebno dodati stavak 4. u okviru članka 148. postavljajući odredbu o kojom bi se jasno naznačila presumpcija istovremenosti, onako kako je to slučaj u Federaciji BiH.

Usp. U Republici Hrvatskoj - čl. 10. Zakona o nasljeđivanju (NN 48/2003, 163/2003, 35/2005, 127/2013, 33/2015, 14/2019) (HR); u Bosni i Hercegovini - čl. 11. Zakona o nasljeđivanju u FBiH (SN 80/2014 i 32/2019 - odluka US) (BA) i čl. 10. Zakona o nasljeđivanju Republike Srpske (SG 1/2009, 55/2009 - ispr. 91/2016, 28/2019 - odluka US i 82/2019) (BA).

Kreč (n 73) 35.

82 Usp. Nov. 118, 1. Nam in usu earum rerum, qui debet adquiri aut servari, nostras de his leges parentibus custodimus, sic tamen ut si quem horum descendentium filios relinquentem mori contigerit, illius filios aut filias aut alias descendentes in proprii parentis loco succedere, sive sub potestate defuncti sive suae potestatis inveniantur, tantam de hereditate morientis accipientes partem, quanticumque sint, quantam eorum parens si viveret habuisset: quam successionem in stirpes vocavit antiquitas. 


\section{O AKTUALNOSTI CASUUM COMMORIENTIUM U EUROPSKOM KONTEKSTU}

U svrhu aktualiziranja pitanja komorijenata u suvremenom europskom pravu obratili smo pozornost na praksu sudova u Europi. Osobito interesantnim čini nam se predmet "Scarle", u kojem je 13. kolovoza 2019. godine konačnu presudu donio Visoki sud Engleske i Walesa (EWHC).$^{84} \mathrm{U}$ činjeničnom stanju predmeta stoji kako je policija dana 11. listopada 2016. godine, u obiteljskoj kući u mjestu Leigt on Sea, nedaleko od Londona, pronašla mrtve gospodina Scarlea (79 godina) i gospođu Scarle (69 godina). Zbog nemogućnosti preciznog određenja vremena smrti primijenjena je zakonska presumpcija utvrđena relevantnim engleskim pravom, odnosno članak 184. Zakona o imovinskom pravu iz 1925. godine. Primjenom utvrđene presumpcije smatrat će se kako je gospodin Scarle preminuo prvi, budući da njihov zakon primijenjuje koncept nadživjelosti sa starosnim kriterijem. ${ }^{85}$ Prema oporuci gospodina Scarlea cjelokupna njegova imovina nakon smrti ima prijeći u vlasništvo gospođe Scarle. Cjelokupna situacija biva usložnjena budući da i gospođa i gospodin Scarle imaju kćeri iz svojih ranijih brakova. Gospođa Scarle također je sačinila oporuku i u istoj naznačila kako nakon smrti svoju cjelokupnu imovinu ostavlja kćeri Deborah Cutler. Primjenjujući dosljedno članak 184. Zakona, presumira se kako je gospodin Scarle prvi umro, a time je njegov dio u okviru zajedničke imovine prešao na gospođu Scarle, koju onda nasljeđuje njezina kći. Kći gospodina Scarle, Ann Winter, očito nezadovoljna primjenom ovakve presumpcije, podnosi zahtjev i pokušava dokazati na sudu kako je gospođa Scarle umrla prva. U tom slučaju oporuku gospodina Scarlea ne bi bilo moguće realizirati i imovina bi prema zakonskom nasljednom redu prešla na nju, kao njegovu kćer. Sudac je uzeo u obzir svjedočenja kćeri i susjeda, post mortem dokaze, policijske zapisnike te vještačenja forenzičkih patologa. Kći gospodina Scarle pokušala je uvjeriti suca kako dokazi pobijaju presumpciju prema kojoj je njezin otac prvi umro. Razmotrivši dostupne dokaze, sudac je zaključio da su i gospodin i gospođa Scarle umrli od hipotermije u neko vrijeme između 5. i 9. listopada 2016. godine, ali da je redoslijed smrti ostao neizvjestan. Kao rezultat toga, sudac je zaključio da se primjenjuje presumpcija smrti iz članka 184. Zakona o imovinskom pravu iz 1925. godine prema kojoj je gospođa Scarle nadživjela gospodina Scarlea. Slijedom toga, kći gospođe Scarle dobila je cjelokupnu imovinu.

Općepoznato je kako je Engleska u okviru modernog europskog prava ostala ponajviše izvan utjecaja rimskog prava. Vjerojatno, upravo zbog te činjenice i nedovoljnog prodora prandektističke pravne misli od 19. stoljeća, koja je možda najzaslužnija za prilagodbu rješenja rimskog prava današnjoj primjeni, svjedočimo primjeni arhaičnog koncepta komorijenata kakav je propisan člankom 184. Zakona o imovinskom pravu na području Engleske i Walesa. Presumpcija koja se primjenjuje i koja redoslijed smrti utvrđuje prema kriteriju starosti, kako smo ranije ukazivali, ne zadovoljava elemente vjerojatnosti, što nužno označava kako nije ni pravično rješenje. Da je, kojim slučajem, na području Engleske bio u primjeni koncept istovremenosti, koji je i praktičniji i logički razumljiviji u situacijama kada nije moguće utvrditi

84 Scarle v Scarle [2019] EWHC 2224 (Ch)

85 Law of Property Act $1925 \S 184$. Presumption of survivorship in regard to claims to property. In all cases where, after the commencement of this Act, two or more persons have died in circumstances rendering it uncertain which of them survived the other or others, such deaths shall (subject to any order of the court), for all purposes affecting the title to property, be presumed to have occurred in order of seniority, and accordingly the younger shall be deemed to have survived the elder. 
točan redoslijed smrti, i kći gospodina Scarlea i kći gospođe Scarle dobile bi dio imovine koji je pripadao ocu gospođe Winter, odnosno majci gospođe Cutler.

U kontekstu razvoja prava na području Engleske i Walesa, iznenađujuće je da u tako dugom razdoblju od donošenja Zakona o imovinskom pravu nije došlo do izmjena u odnosu na postavljenu presumpciju. Nije isključeno kako će određene izmjene uslijediti upravo zbog predmeta "Scarle", koji je britanska javnost pratila i preko medijskih izvješća. ${ }^{86}$ Štoviše, smatramo kako te izmjene, ako ne zbog prilagodbe pravičnijem rješenju, trebaju biti usvojene u cilju doprinosa nastavku procesa harmoniziranja privatnog prava u Europi. Neovisno o tome što Velika Britanija i službeno od 1. veljače 2020. godine nije dio Europske unije, harmonizacija europskog privatnog prava treba predstavljati kontinuitet doprinosa stvaranju ius commune europeum koji prema svom meritumu predstavlja širi pojam od samog acquis communautaire privatum i uključuje cjelokupno europsko privatno pravo izgrađeno na rimskoj pravnoj tradiciji.

Kad je riječ o samoj Europskoj uniji, pitanje komorijenata regulirano je člankom 32. Uredbe o nasljeđivanju iz 2012. godine. ${ }^{87}$ Ovom Uredbom nastojalo se doprinijeti harmoniziranju europskog prava regulirajući nadležnosti, mjerodavna prava, priznanja i izvršenja odluka te provedbu određenih autentičnih instrumenata u procesu nasljeđivanja. ${ }^{88}$ Pitanje komorijenata regulirano je primjenom koncepta istovremenosti. ${ }^{89}$ Sama norma ima supsidijaran karakter, odnosno njezina primjena je obvezna, samo onda kada utvrđujemo redoslijed smrti osoba čije nasljeđivanje uređuju različita prava ili ako nacionalno pravo države članice nema relevantnu odredbu o ovom pitanju. ${ }^{90}$ Važno je naglasiti kako je riječ o prvom materijalnopravnom pitanju reguliranom u okviru novog međunarodnog nasljednog prava Europske unije, što uistinu ukazuje na značaj samog instituta i izvjesno potvrđuje našu tezu o ozbiljnim praktičnim reperkusijama koje može izazvati njegova nereguliranost ili neadekvatna primjena. Na kraju, valja istaknuti, neovisno o supsidijarnom karakteru, nedvosmisleno je potvrđena kvaliteta koncepta istovremenosti i tendencija njegova prevladavanja u suvremenom europskom privatnom pravu.

\section{ZAKLJUČCI}

U rimskoj pravnoj tradiciji, u cilju rješavanja casuum commorientium, dolazi do razvoja različitih pravnih presumpcija još od razdoblja klasičnog rimskog prava. Sve te presumpcije

86 Usp. Judge rules in 'extraordinary' Essex inheritance case, BBC News (Essex, 13 August 2019) <https://www.bbc.com/news/ukengland-essex-49337332> pristupljeno 13. studenog 2020.

87 Unutar Europske unije i dalje su prisutne razlike u pristupu pitanju komorijenata. Više vidi: Anatol Dutta, 'Succession and Wills in the Conflict of Laws on the Eve of Europeanisation' (2009) 3 Rabels Zeitschrift für ausländisches und internationales Privatrecht 598-99.

88 Angelo Davi and Alessandra Zanobetti, 'Il nuovo diritto internazionale privato delle successioni nell'unione Europea' (2013) 5(2) Cuadernos de Derecho Transnacional 20.

89 Uredba (EU) 650/2012 o nasljednim stvarima i o uspostavi europske potvrde o nasljeđivanju, čl. 32. Ako dvije ili više osoba čije nasljeđivanje uređuju različita prava umru u okolnostima u kojima nije sigurno kojim redoslijedom su nastupile njihove smrti te ako ta prava drukčije propisuju za takvu situaciju ili uopće o tome nemaju odredbi, nijedna od umrlih osoba nema bilo koja prava na nasljedstvo druge ili drugih osoba.

90 Usp. Anatol Dutta, 'Novo međunarodno nasljedno pravo Evropske unije: prvo čitanje Uredbe o nasljednom pravu' [2013] Nova pravna revija 17; Selma Mezetović Međić, 'Uredba 650/2012: na putu prema evropskom nasljednom pravu' (2015) 58 Godišnjak Pravnog fakulteta u Sarajevu 182. 
moguće je sistematizirati u okviru dvaju osnovnih koncepata - prvog utemeljenog na presumiranju nadživjelosti pojedinih subjekata i drugog utemeljenog na presumiranju istovremenosti smrti subjekata. Rimsko pravo nije postavilo pravila o isključivanju postavljenih koncepata pa je primjena jednog ili drugog koncepta ovisila o konkretnoj situaciji. Prema prvom konceptu utvrđena su određena pravila u okviru kojih se uzimalo da su pojedini subjekti nadživjeli druge ovisno o većem broju različitih determinanti koje su najčešće bile vezane uz prirodne osobine (zdravlje, starost, spol i drugo). Također, katkad su pravna mišljenja, odnosno postavljene presumpcije opravdavane određenim carskim uredbama ili razlozima humanosti, no u većini situacija naznačenih u izvorima nema drukčijeg obrazloženja, osim da su pravnici vjerojatnost preživljavanja procjenjivali prema općoj snazi prosječnih pojedinaca u određenim životnim fazama. Ovo pitanje opće snage pojedinaca čini se potpuno logičnim, ali nije u nužnoj korelaciji sa slijedom umiranja na što smo ukazali i na temelju medicinskih mišljenja. U konačnici, to će vjerojatno i doprinijeti uočavanju potrebe za odbacivanjem ovakvog koncepta. Drugi koncept zasnovan na istovremenosti, bit će izgrađen na stavu prema kojem nije moguće pretpostavljati da je određena osoba drugu nadživjela na temelju svojih prirodnih osobina u situacijama kada to nije moguće sa sigurnošću utvrditi. Na temelju tako postavljene presumpcije, u okviru ovog koncepta, smatrat će se da niti jedan od subjekata u okviru casus commorientis nije bio živ u trenutku otvaranja nasljedstva drugog, što u konačnici predstavlja logično, ali i vrlo praktično rješenje za predmetne situacije.

Posebnu pozornost posvetili smo mogućnosti primjene presumpcija u odnosu na slučajeve kada između smrti osoba postoji određena prostorna ili vremenska udaljenost ili ako je različit uzrok doveo do smrtnih posljedica. Analizom rimskih pravnih izvora zaključili smo kako je u ovakvim situacijama postavljen uvjet uspostave veze između smrti dviju ili više osoba i određenog nesretnog događaja. Iz navedenog proizlazi da smrt osoba mora biti prouzrokovana istim događajem ili šire promatrajući istom katastrofom. U pandektistici o ovom su pitanju bili podijeljeni stavovi. Za razliku od autora koji su ovo pitanje promatrali vrlo restriktivno, inzistirajući na konkretno postavljenom uzroku smrti ili drugih koji su navedenom pitanju pristupili preširoko ostavljajući mogućnost primjene u svakoj situaciji kada nije moguće sa sigurnošću utvrditi redoslijed smrti osoba, mi smo ukazali na važnost "srednjeg puta" koji je naslonjen na rješenja rimskog prava. Njegovom primjenom ostavljen je prostor za primjenu koncepta i onda kada ne znamo konkretan uzrok smrti, ali sa sigurnošću znamo kako je smrt uzrokovana određenim događajem ili je u vezi s istim.

Poredbeno promatrajući u razvoju europskog privatnog prava došlo je do recepcije obaju rimskih koncepata. Tako je u Francuskoj, donošenjem Code civila, pitanje komorijenata bilo riješeno primjenom koncepta nadživjelosti pojedinih subjekata, uzimajući na prvom mjestu okolnosti slučaja, a ako ih nema, onda primjenom kriterija dobi ili spola. Slična rješenja bit će recipirana i na području Belgije, Nizozemske, Srbije te dijelova Njemačke tijekom 19. stoljeća. Austrijski građanski zakonik prvi će u modernom europskom pravu ovo pitanje normirati primjenom rimskog koncepta istovremenosti. Ovakav koncept bit će prihvaćen i u talijanskom Codice civile te Švicarskom građanskom zakoniku. Njemački građanski zakonik, također će u procesu normiranja primijeniti koncept istovremenosti, ali uz izričit zahtjev ispunjenja kriterija "iste katastrofe". Bez ulaska u dublju analizu, naznačili smo kako je na ovakvo rješenje možda utjecao i osobno Windscheid, imajući u vidu njegove poglede o pitanju primjene ovog instituta. Do određenog popuštanja vezanih uz kriterij "iste katastrofe" u Njemačkoj će doći 
donošenjem Zakona o nestanku, proglašenju smrti i određivanju vremena smrti od 4. srpnja 1939. godine.

Koncept istovremenosti, kao logičniji i praktičniji u procesu rješavanja casuum commorientium s vremenom će potisnuti koncept nadživjelosti u europskom pravu. Do zamjene koncepta nadživjelosti u Francuskoj doći će 2001. godine. Osim toga, unutar Europske unije, Uredbom o nasljeđivanju iz 2012. godine, normirajući određene autentične instrumente supsidijarnog karaktera u procesu nasljeđivanja, normirano je i pitanje komorijenata. Jasno je primijenjen koncept istovremenosti, što jasno potvrđuje tendenciju općeg prihvaćanja ovakvog koncepta u europskom privatnom pravu. U odnosu na navedeno, ukazali smo i kako je na području Engleske i dalje u primjeni arhaični koncept komorijenata kojim se presumira redoslijed smrti prema kriteriju starosti. Ukazali smo na nužnost izmjene ovakvog rješenja, prvenstveno zbog prilagodbe pravičnijem rješenju, ali i doprinosa harmonizaciji i izgradnji ius commune europeum.

U pogledu prava na području današnje Republike Hrvatske i Bosne i Hercegovine vidljivo je kako je casus commorientes reguliran primjenom koncepta istovremenosti, a na tragu rješenja utvrđenih Austrijskim građanskim zakonikom. Štoviše, na području RH i Federacije BiH institut je normiran odredbama zakona o nasljeđivanju, dok je na području bosanskohercegovačkog entiteta Republika Srpska i danas u primjeni pravno pravilo OGZ-a, primjenjivo sukladno odredbama Zakona o nevažnosti pravnih propisa donesenih prije 6. travnja 1941. godine i za vrijeme neprijateljske okupacije. ${ }^{91}$

Shodno cjelokupnom izlaganju, čini nam se kako smo uspješno ukazali na aktualnost ovih pitanja te na temelju analize rimskih pravnih izvora razriješili određene nedoumice do kojih bi moglo doći u primjeni instituta. U tom smislu, razumijevajući važnost rimskih pravila koja katkad mogu imati fundamentalni značaj u razumijevanju instituta suvremenog privatnog prava, raščlanili smo i otvorili diskusiju o nekim pitanjima poput kriterija zadovoljavanja "iste katastrofe", što praktično promatrajući može biti od osobitog značaja u procesu rješavanja konkretnih predmeta u praksi.

\section{BIBLIOGRAFIJA}

1. Bećić M, 'Historijska i pravna osnovanost primjene Općeg građanskog zakonika u BiH nakon okupacije 1878. godine' [2011] 54 Godišnjak Pravnog fakulteta u Sarajevu 63

2. Berger A, Encyclopedic Dictionary of Roman Law (American Philosophical Society 1953)

3. Biondi B, Il diritto Romano (Editore Licino Cappelli 1957)

4. Blagojević B, Nasledno pravo FNRJ (Naučna knjiga 1955)

5. Bonfante P, Istituzioni di diritto Romano (Casa Editrice Dott. F. Vallardi 1925)

6. Creteau E and Rostovtseva N, 'The Concept of Commorientes in French and Russian Inheritance Law’ (2020) 8(1) Russian Law Journal 4

91 Op. a. U bosanskohercegovačkom entitetu Republika Srpska su čl. 12. Ustavnog zakona za provedbu Ustava Republike Srpske u pravni poredak Republike Srpske preuzeti svi savezni zakoni bivše SFRJ pod uvjetom da nisu u suprotnosti s važećim pravnim poretkom (SG 21/1992) (BA). 
7. Davi A and Zanobetti A, 'Il nuovo diritto internazionale privato delle successioni nell'unione Europea' (2013) 5(2) Cuadernos de Derecho Transnacional 5

8. Du Plessis PJ, Ando C and Tuori K (eds), The Oxford Handbook of Roman Law and Society (OUP 2016)

9. Duncan J and Derrett M, Essays in Classical and Modern Hindu Law, vol 3 (Brill 1977)

10. Dutta A, 'Novo međunarodno nasljedno pravo Evropske unije: prvo čitanje Uredbe o nasljednom pravu' [2013] Nova pravna revija 9

11. Dutta A, 'Succession and Wills in the Conflict of Laws on the Eve of Europeanisation' (2009) 3 Rabels Zeitschrift für ausländisches und internationales Privatrecht 547

12. Egersdorfer A, Predavanja dr. Aleksandra Egersdorfera o pandektama, vol 1 (Naklada Jugoslovenske štampe 1928)

13. Eisner B i Horvat M, Rimsko pravo (Nakladni zavod Hrvatske 1948)

14. Eisner B, Pandekta (Klub slušača prava 1938)

15. Ferrini C, Le presunzioni in diritto romano (Ermanno Loescher 1878)

16. Gavella N i Belaj V, Nasljedno pravo (Narodne novine 2008)

17. Gavella N, 'Građansko pravo u Hrvatskoj i kontinentalnoeuropski pravni krug: u povodu 140. godišnjice stupanja na snagu OGZ u Hrvatskoj' (1993) 43(4) Zbornik Pravnog fakulteta u Zagrebu 335

18. Goodman M, The Roman World 44 BC - AD 180 (Routledge 1997)

19. Hamza G, 'Réflexions sur les présomptions relatives aux personnes décédées dans le même événement en droit romain' (1993) 34 Annales Universitatis Scientiarum Budapestinensis de Rolando Eotvos Nominatae: Sectio Iuridica 15

20. Hamza G and Sajó A, 'Az együtt elhalás néhány jogi kérdése' (1976) 3 Magyar Jog 191

21. Hebib M, 'Razvoj pogrebnog prava u rimskoj pravnoj tradiciji' (2020) 57(3) Zbornik radova Pravnog fakulteta u Splitu 851

22. Hof Wallace M, 'A Primer on Absent Persons in Louisiana' (2018) 64(2) Loyola Law Review 423

23. Hohmann H, 'Presumptions in Roman Legal Argumentation' in Hans V Hansen and others (eds), Argumentation and its Applications: Proceedings of the Ontario Society for the Study of Argumentation Conference - OSSA4 (Ontario Society for the Study of Argumentation 2001)

24. Horvat M, Rimsko pravo (Pravni fakultet u Zagrebu 2017)

25. Josipović T, '200 Jahre der ABGB-Anwendung in Kroatien - 135 Jahre als Gesetz und 65 Jahre als "Rechtsregeln"' in Constanze Fischer-Czermak and others (eds), Festschrift 200 Jahre ABGB (Manz Verlag 2011) 157-74

26. Kaser M, 'Beweislast und Vermutung im römischen Formularprozess' (1954) 71(1) Zeitschrift der Savigny - Stiftung für Rechtsgeschichte. Romanistische Abteilung 221

27. Kaser M, Das römische Privatrecht (Beck 1955)

28. Keppie L, The Makring of the Roman Army from Republic to Empire (Routledge 1998)

29. Kirchstetter L, Commentar zum Oesterreichischen Allgemeinen bürgerlichen Gesetzbuche mit vorzüglicher Berücksichtigung des gemeinen deutschen Privatrechts (Brockhaus 1876)

30. Kranjc J, Rimsko pravo (Ius Software \& GV Založba 2017)

31. Kreč M i Pavić Đ, Komentar Zakona o nasljeđivanju (Narodne novine 1964)

32. Lambertini R, La problematica della commorienza nell' elaborazione giuridica romana (Giufre 1984)

33. Macagno F i Walton D, 'Presumptions in Legal Argumentation' (2012) 25(3) Ratio Juris 271

34. Madea B (ed), Handbook of Forensic Medicine (Wiley Blackwell 2014) 
35. Malenica A i Deretić N, Rimsko pravo (Pravni fakultet u Novom Sadu 2011)

36. Mezetović Međić S, 'Uredba 650/2012: na putu prema evropskom nasljednom pravu' (2015) 58 Godišnjak Pravnog fakulteta u Sarajevu 165

37. Mousourakis G, Fundamentals of Roman Private Law (Springer 2012)

38. Mugdan B, Die gesammten Materialien zum Bürgerlichen Gesetzbuch für das Deutsche Reich, vol 1 (Decker 1899)

39. Nótári T and Papp T, 'The problem of simultaneous death in the law of inheritance: historical and comparative approaches' [2013] 2 Fiat Iustitia 12

40. Perić B, Struktura prava (Informator 1994)

41. Petrak M, 'Rimsko pravo kao pozitivno pravo u Republici Hrvatskoj: prilog tumačenju Zakona o načinu primjene pravnih propisa donesenih prije 6. travnja 1941. godine' (2006) 6(10) Hrvatska pravna revija 1

42. Pezo V (ed), Pravni leksikon (Leksikografski zavod Miroslav Krleža 2007)

43. Planck G, Planck's Kommentar zum Bürgerlichen Gesetzbuch, vol 1 (De Gruyter 1913)

44. Povlakić M, 'Der mehr als einhundertjährige Einfluss des ABGB in Bosnien und Herzegowina' in Constanze Fischer-Czermak and others (eds), Festschrift 200 Jahre ABGB (Manz Verlag 2011) 223-52

45. Puhan I, Rimsko pravo (Naučna knjiga 1969)

46. Radoman D, 'Casus commorientium u rimskom i suvremenim pravima' (1977) 27(4) Zbornik Pravnog fakulteta u Zagrebu 325

47. Radoman D, 'Dve pretpostavke o komorijentima' (1958) 7(9) Glasnik advokatske komore Vojvodine 2

48. Radovčić V, 'Nešto o rimskim presumpcijama kod zajedničke smrti više osoba u istoj nesreći' (1964) 14(3-4) Zbornik Pravnog fakulteta u Zagrebu 159

49. Radovčić V, 'Pokušaj kodifikacije građanskog prava u staroj Jugoslaviji (Predosnova građanskog zakonika za kraljevinu Jugoslaviju)' (1975) 7(1) Radovi 249

50. Regelsberger F, Pandekten (Duncker \& Humbolt 1893)

51. Riter von Arnesberg C. L. A, Pandekte ili današnje rimsko pravo, vol 1 (A Đordević i DT Mijušković tr, Kraljevska srpska državna štamparija 1890)

52. Roeleveld L, ‘Questions Concerning Simultaneous Death’ [1970] Acta Juridica 31

53. Romac A, Latinske pravne izreke (Globus 1982)

54. Schoeman-Malan L, 'Comparative Analysis of Commorientes: A South African Perspective: part I' (2017) 50(2) De Jure 36

55. Stanojević O, Rimsko pravo (Magistrat 2000)

56. Stojčević D, Rimsko privatno pravo (Savremena administracija 1978)

57. Klarić P i Vedriš M, Građansko pravo (Narodne novine 2006)

58. Visković N, Teorija države i prava (Birotehnika 2001)

59. Volterra E, Istituzioni di diritto privato romano (Edizioni Ricerche 1961)

60. Windscheid B, Lehrbuch des Pandektenrechts (Julius Buddeus 1875) 


\section{PROPISI I DOKUMENTI}

1. Austrijski građanski zakonik (D Aranđelović tr, Nova štamparija - Davidović 1906)

2. Code civil 1804 (version en vigueur au 03 novembre 2021) (FR) <https://www.legifrance.gouv.fr/> pristupljeno 15. listopada 2020.

3. Codice civile del Regno d'Italia (Stamperia Reale 1865) (IT)

4. Codice Civile Svizzero (del 10 dicembre 1907) $(\mathrm{CH})<$ www.fedlex.admin.ch> pristupljeno 23. studenog 2020.

5. Corpus Iuris Civilis ${ }^{92}$

6. Das Bürgerliche Gesetzbuch (1 Fassung - Reichsgesetzblatt 1896, ausgegeben am 24. 08. 1896, in Kraft seit 01. 01. 1900) (DE) <https://www.gesetze-im-internet.de/bgb/> pristupljeno 1. studenog 2020.

7. Law of Property Act 1925 (UK) <www.legislation.gov.uk> pristupljeno 10. studenog 2020.

8. Todeserklärungsgesetz (BGBI 23/1951), bilj §1-11 des Gesetzes über die Verschollenheit, die Todeserklärung und die Feststellung der Todeszeit vom 4 Juli 1939, Deutsches RGBI. I S. 1186 (DE)

9. Uredba (EU) 650/2012 o nasljednim stvarima i o uspostavi europske potvrde o nasljeđivanju <https://eur-lex.europa.eu/legal-content/hr/LSU/?uri=CELEX\%3A32012R0 650> pristupljeno 11. studenog 2020.

10. Ustavni zakon za provedbu Ustava Republike Srpske (SG 21/92) (BA)

11. Verschollenheitsgesetz (DE) <www.gesetze-im-internet.de> pristupljeno 10. prosinca 2020.

12. Zakon o nasleđivanju Republike Srbije (SG 46/95, 101/2003 - odluka USRS i 6/2015) (RS)

13. Zakon o nasljeđivanju (NN 48/2003, 163/2003, 35/2005, 127/2013, 33/2015, 14/2019) (HR)

14. Zakon o nasljeđivanju FNRJ (SL 20/1955) (YU)

15. Zakon o nasljeđivanju Republike Srpske (SG 1/2009, 55/2009 - ispr 91/2016, 28/2019 - odluka US i 82/2019) (BA)

16. Zakon o nasljeđivanju u FBiH (SN 80/2014 i 32/2019 - odluka US) (BA)

17. Zakon o nevažnosti pravnih propisa donesenih prije 6. travnja 1941. godine i za vrijeme neprijateljske okupacije (SL 86/1946) (YU)

18. Zakon o proglašenju nestalih osoba za umrle i o dokazivanju smrti (SL 24/52, 26/52) (YU)

19. Zakon od 31. marta 1918. kojim se mijenja zakon od 16. februara 1883. o postupku u svrhu proglašenja smrti i dokazivanja smrti, dostupno (Lista državnih zakona kraljevine i zemlje zastupane u carevinskom vijeću, vol 61, 1918) 339-40

\section{PRESUDE I DRUGE ODLUKE}

1. Scarle v Scarle [2019] EWHC $2224(\mathrm{Ch})$

92 Obrada rimskih pravnih izvora izvršena je korištenjem sustava: BIA - Bibliotheca iuris antiqui, Sistema informativo integrato sui diritti dell'antichità, Direzione scientifica di Nicola Palazzolo, Milano 2000. 
198

\section{MREŽNI IZVORI}

1. - - Judge rules in 'extraordinary' Essex inheritance case, BBC News (Essex, 13 August 2019) <https://www.bbc.com/news/uk-england-essex-49337332> pristupljeno 13. studenog 2020. 
Mirza Hebib*

\section{ON THE ACTUALITY OF CASUUM COMMORIENTIUM IN ROMAN AND CONTEMPORARY EUROPEAN PRIVATE LAW}

\section{Summary}

In the Roman legal tradition, but also in modern civil law systems, the term commorientes (lat. commorientes) refers to persons who died in the same accident or other danger, standing in a legal position relevant to inheritance law. In connection with the resolution of such situations in the theory of private law, various legal presumptions have been developed since the period of classical Roman law. All these presumptions can be systematized within two basic concepts - the first based on the presumption of survival of subjects and the second based on the presumption of the simultaneous death of subjects.

Comparatively, in the development of European private law, there has been a reception of both concepts, with the proviso that over time the concept of simultaneity will almost completely suppress the concept of survival. The paper analyzes the reasons for this. In establishing a link between Roman roots and European private law, special attention is given to the possibility of applying presumptions in cases where there is a certain spatial or temporal distance between the deaths of persons or if a different cause has led to fatal consequences. Ultimately, the paper clearly points to the importance of Roman rules, which can sometimes be fundamental in understanding the institutes of contemporary private law.

Keywords: $\quad$ commorientes, Roman law, inheritance law, European Private Law, Code Civil, German Civil Code, Austrian Civil Code 
